\title{
Wind and Solar Power in the Transition to a Low-Carbon Economy
}

Electricity generation using fossil fuels contributed 31 percent of global GHG emissions in 2014. ${ }^{1}$ Those emissions are on the verge of irrevocably damaging the global climate system, with serious economic and environmental effects already appearing. The scientists on the Intergovernmental Panel on Climate Change (IPCC) have concluded that switching to low-carbon sources of electricity, including both wind and solar power, is one of the fastest and most cost-efficient ways to reduce future carbon in the atmosphere (Intergovernmental Panel on Climate Change 2014: 20). ${ }^{2}$ The global climate system ultimately needs a low-carbon transition that not only increases wind and solar power but also decreases existing GHG-dense sources of electricity like coal and forgoes adding future capacity for those sectors. This is a more zero-sum view of electricity choices than appears in the other chapters of this book because it focuses as much on sunsetting the old as on promoting new kinds of electricity (Hess 2018: 178; Princen, Manno, and Martin 2015). The problem also has the longest time frame, as climate change builds and must be addressed over decades.

These observations establish the structure of interests in the climate policy arena that was already laid out in Chapter 1. First, there is a general, but diffuse, interest in establishing institutions and policies that reduce GHG emissions to avoid future climate change. Building wind and solar power can advance this aim. Interests like this generate supporting coalitions - if they exist at all - that form wide and shallow

1 Climate Watch, “Global Historical Emissions,” www.climatewatchdata.org/gh g-emissions? breakBy=sector\&chartType=percentage.

2 Following common usage, I refer to this as decarbonization and a low-carbon transition, although the aim is to reduce all greenhouse gases, not only carbon.

Wind and solar powered electricity are not free of greenhouse gas emissions, but they are among the lowest-carbon options. A lifecycle analysis of the emissions associated with wind $\left(34 \mathrm{~g} \mathrm{CO}_{2} \mathrm{e} / \mathrm{kWh}\right)$ and solar PV $\left(50 \mathrm{~g} \mathrm{CO}_{2} \mathrm{e} / \mathrm{kWh}\right)$ is much lower than that of coal (960 $\mathrm{g} \mathrm{CO}_{2} \mathrm{e} / \mathrm{kWh}$ with scrubbing; 1050 without) (Nugent and Sovacool 2014: 241). 
networks, often targeting the elections and legislatures where broad policies are set (Schneider 2004: 475). They will go well beyond the electricity sector itself. It is not unusual for coalitions in favor of climate action to also include both principled activists and those with concrete self-interests in climate action, including those committed to a just transition (Hochstetler and Viola 2012; Kelsey and Zysman 2014: 85-86; Newell and Mulvaney 2017).

At the same time, there is a potential second set of interests in the climate policy arena: when the existing electricity supply is based on fossil fuels, the fossil fuel sector has an intense interest in resisting these developments (Downie 2018; Moe 2015). Such fossil fuel sectors typically have substantial structural and mobilizational power that is "locked in" by being embedded in physical infrastructures, social institutions, political power relations, and prevailing norms (Geels 2004; Jacobsson and Lauber 2006; Meadowcroft 2009; Mitchell 2011; Unruh 2000). Facing an existential threat, the sector would be expected to form close networks to lobby and pursue its interests in maintaining the status quo (Schneider 2004: 468). Accelerating energy transition may depend on the weakening of this sector (Roberts and Geels 2019: 225).

While all countries share the diffuse interest in climate action, only some will have an electricity sector that is grounded in fossil fuels. Those countries will face considerably more contention over renewable energy if the interest structure of the climate change arena drives wind and solar power outcomes. The status quo coalition could either challenge the formulation of general climate plans or resist the implementation of those plans by trying to block growth of wind and solar power in the electricity matrix in particular. Final renewable energy outcomes will depend on the balance of power between the coalitions supporting energy transition and those defending the status quo. For countries without such a fossil fuel sector, pursuing climate action should translate more straightforwardly into more wind and solar power.

Given the structure of interests just outlined, climate policy formulation and its implementation in the electricity sector require a strong state that is oriented toward seeing long-term strategic needs to address climate change. It must be able to promote solutions even when they mean imposing costs on powerful actors with vested interests in the status quo (Meckling and Nahm 2017: 741; Pearson and Foxon 2012: 121). 
Consequently, this chapter has a theoretical focus on state capacity, both in the positive sense of the ability to plan and execute policy that provides public goods - here, mitigating climate emissions - and in the negative sense of the ability to confront powerful societal interests (Cingolani, Thomsson, and Crombrugghe 2015; Evans 1995; Evans, Rueschemeyer, and Skocpol 1985; Power et al. 2016). This will be especially critical for countries with a well-developed electricity sector based on fossil fuels, such as South Africa. As a result, Brazil and South Africa represent strikingly different variations on the challenge of a low-carbon transition and, correspondingly, they position wind and solar power very differently in their climate politics and policy.

In South Africa, which depended on coal for 95 percent of its electricity supply until 2013, high carbon intensity in a historically privileged coal-based electricity sector has in fact led to a pitched battle between the coalitions for and against energy transition. As I trace in more detail in Section 2.2, this battle over climate change policy was not fought openly. Both sides accepted the need for climate action but differed on what that might require. The two decades up to 2009 saw a steady increase in state capacity to formulate first environmental and then more specifically climate policy, although environmental agencies continued to depend on civil society and the electricity parastatal Eskom for some tasks. Public debate on climate action was muted, with ongoing indecision about the level of South Africa's climate ambitions, until former president Jacob Zuma suddenly announced an international climate action commitment at the Copenhagen negotiations in 2009. After that, the debate spilled into the open. The Department of Environmental Affairs (DEA) continued to build climate capacity with a burst of activity after 2010 but could not manage what became increasingly heated debate over just how any climate commitment would be implemented in the electricity build plan. Eskom led a status quo coalition that fought increasingly hard to keep wind and solar power out of the build plan, arguing for nuclear power instead. Large nuclear installations built by Eskom would have retained more of its historical position in the sector. Subsequent developments have shown that the status quo coalition's theoretically expected opposition to energy transition was reinforced by the Zuma administration's corruption of Eskom and the electricity sector that also led to the preference for nuclear power. The renewable energy outcomes of these battles were repeated fits and starts (see Figure 1.1 in Chapter 1). 
In Brazil, the hydro-based electricity sector is already comparatively low carbon, and GHG emissions have been concentrated in deforestation and the nonelectricity energy sector. The country also built environmental capacity over decades that culminated in striking decreases in deforestation and its associated emissions after 2005. Wide, if shallow, political consensus and electoral considerations also set out new climate policies and institutions after that, although agribusiness interests pushed back hard as they regained political power after 2011 and especially under President Jair Bolsonaro (2019-2023). These debates largely operated without reference to wind and solar power, however. A more technocratic style of decision-making continued in the electricity sector itself, as expected given the lack of strong actors linked to fossil fuel sources of electricity. Yet those technocrats were clearly not following a climate logic as they expanded wind power after 2001 while leaving solar power out of their electricity plans until 2014. Since climate motivations would favor both kinds of renewable energy, the sources of the differences between wind and solar outcomes must be found in other chapters.

I begin this chapter, in Section 2.1, with a discussion of state capacity applied to climate change politics. In Section 2.2, I then show the national debates in South Africa around making climate action commitments at the national and international levels. Section 2.3 then showcases the South African plans for building new electricity generation capacity - and wind and solar power in particular - which visualize the prevailing balance of power for implementing any climate commitments over time. Sections 2.4 and 2.5 do the same for Brazil. The conclusion, in Section 2.6, returns to the question of how well state capacity for climate action accounts for the outcomes of wind and solar power production in the two countries. Overall, the logic of the climate political economy is a significant driver of wind and solar outcomes in South Africa, but less so in Brazil.

\subsection{Understanding Climate Action as a Question of State Capacity}

Scholars of comparative political economy have a long-standing interest in understanding state capacity (Cingolani et al. 2015; Evans et al. 1985; Kohli 2004; Kurtz 2013; Weiss 1998). Little of this literature considers climate change or even environmental challenges more 
generally. Even so, a central focus of this literature - whether the state is willing and able to formulate and implement public goals even when they might be opposed by powerful social groups (Cingolani et al. 2015: 193; Meckling and Nahm 2017; Skocpol 1985: 9) - is clearly relevant for climate action. Because the climate political economy potentially activates environmental and economic as well as energy sectors, it requires a wider theoretical framing than the common formulation of regulatory capture that focuses more narrowly on the relationship between only, say, electricity utilities and their regulators (Berry 1984; Mitnick 2011).

A theoretical focus on state capacity requires first justifying a focus on the state. There are few defenders of states among scholars of climate change: they have been slow to make international agreements to address this global problem and slow to fulfill the promises they do make. Many have turned instead to look for action from nonstate or transnational actors from nongovernmental organizations (NGOs) to businesses to cities (Bäckstrand and Kronsell 2015: 1; Bulkeley et al. 2014). States really cannot be ignored, however. They have significant legitimate authority and resources to effectively address climate change, if they choose to do so, a claim institutionalized in the Nationally Determined Contributions that make up the 2015 Paris Agreement on Climate Change. So, three decades after the state was brought back into comparative political economy (Evans et al. 1985), it has to be brought into the comparative political economy of climate change.

Global climate negotiations have also been built around a related preoccupation with state capacity (Willems and Baumert 2003). The negotiations have historically divided national obligations for climate action according to what UN documents routinely refer to as a formula of "common but differentiated responsibilities and respective capabilities" (Bortscheller 2009-2010; Stone 2004). The last clause once exonerated middle-income and developing countries from mandatory climate action under the 1997 Kyoto Protocol except for reporting on voluntary action. Negotiations since then have led to open international disputes over when large and comparatively wealthy and capable developing countries like Brazil and South Africa should commit to undertake action to reduce their climate change emissions (Hochstetler 2012). Both, in fact, made voluntary commitments in Copenhagen in 2009 and joined the Paris Agreement in 2015. Those international debates play a comparatively large role in this chapter. 
Scholars focused on Africa have argued persuasively that environmental stewardship is also critical in middle-income and developing states more generally. In this context, however, any environmental imperative must be balanced with an economic one (Chandrashekeran, Morgan, Coetzee, and Christoff 2017: 4; Death 2016; Swilling and Annecke 2012). This difficult double task is taken on by states that are generally less capable in conventional terms. Nonetheless, bureaucracies that do not look like the Weberian ideal may also govern with some effectiveness, especially embedded in networks that blur state and society and national and international divides (Death 2016: 52; Evans 1995; Hochstetler and Keck 2007: 16-20). If we are to consider the roles of states in addressing environmental imperatives beyond the wealthy, industrialized world, state capacity must be researched rather than just assumed, as it varies significantly. Basic descriptive analysis of the kind provided in this chapter is key to this task (Duit 2016: 70).

Climate researchers have begun to explore the importance of state capacity for explaining climate action. They often focus on the choice of specific instruments for reducing greenhouse gases, mostly in developed countries (e.g., Hughes and Urpelainen 2015; Meckling and Nahm 2017; Willems and Baumert 2003). The analytical choices made do not always make the translation to lower capacity settings, however. For example, in an otherwise exemplary article, Jonas Meckling and Jonas Nahm take bureaucratic capacity for implementation for granted (Meckling and Nahm 2017: 743). Similarly, state capacity is often operationalized as the existence of a relevant agency (e.g., Hughes and Urpelainen 2015: 58). In lower capacity contexts, this is not a safe assumption: the Brazilian Special Secretariat of the Environment would count, although it was created in 1973 with three employees in two rooms and had little real capacity for well over a decade (Hochstetler and Keck 2007: 27). The eventual Ministry of Environment did not even have a professional civil service track until 2003 (Abers and de Oliveira 2015), but it achieved some significant, if precarious, environmental governance with civil society (Hochstetler and Keck 2007: 223-225).

State capacity to formulate and implement policy in advanced developing countries like Brazil and South Africa is especially difficult to gauge in general terms. Both had ambitious authoritarian states that were able to implement demanding visions from apartheid to classic 
developmentalism (Evans 1979; Fine and Rustomjee 1996; Seidman 1994). Even so, they are equally characterized by very uneven levels of capacity. "Islands of excellence" like South Africa's National Treasury (Pearson, Pillay, and Chipkin 2016) coexist with institutions like Eskom, now featuring in reports of "state capture" by narrow interests allied with Zuma (Chipkin and Swilling 2017; Public Protector 2016). Brazil's state agencies also display considerable variation in their levels of capacity and independence (Bersch, Praça, and Taylor 2017). State capacity and independence in the environmental area in both countries is thus less a given than it is struggled over in particular instances (Hochstetler and Keck 2007: 223-225). Contingent coalitions will reflect the distinct political economies of GHG emissions in their national economies and create distinct climate action logics (MacNeil and Paterson 2012; Nahm 2017; Pegels 2014b).

\subsection{South African Climate Capacity and Initiatives}

The basic pattern of GHG emissions in South Africa implies very serious barriers to climate action through building wind and solar power because the electricity sector and the economy are so oriented toward coal, while the Brazilian route should be easier. As Figure 2.1 shows, about 80 percent of the GHG emissions in South Africa are linked to the energy sector, so South Africa simply cannot reduce its GHG emissions in any significant way without replacing its coal generation with renewable energy (Winkler 2009). This means that South African climate politics displays the full array of interests just outlined: as the government began to articulate a diffuse and general interest in climate action, opposition rose from a highly concentrated set of interests that defend ongoing coal mining and coal-based electricity generation.

It is straightforward to identify the actors positioned on either side of energy transition in South Africa. The side of the traditional coal-based mining economy had strong support in the governing ANC party, the parastatal Eskom, and the powerful industry groups and state agencies of the "Minerals-Energy Complex" (Fine and Rustomjee 1996; McDonald 2011). On the other side, an incipient counter-economy has wind and solar power at its center (Baker 2015a; Baker, Newell, and Phillips 2014; Power et al. 2016). The state institutions most closely related to the counter-economy are the DEA and sometimes the National 


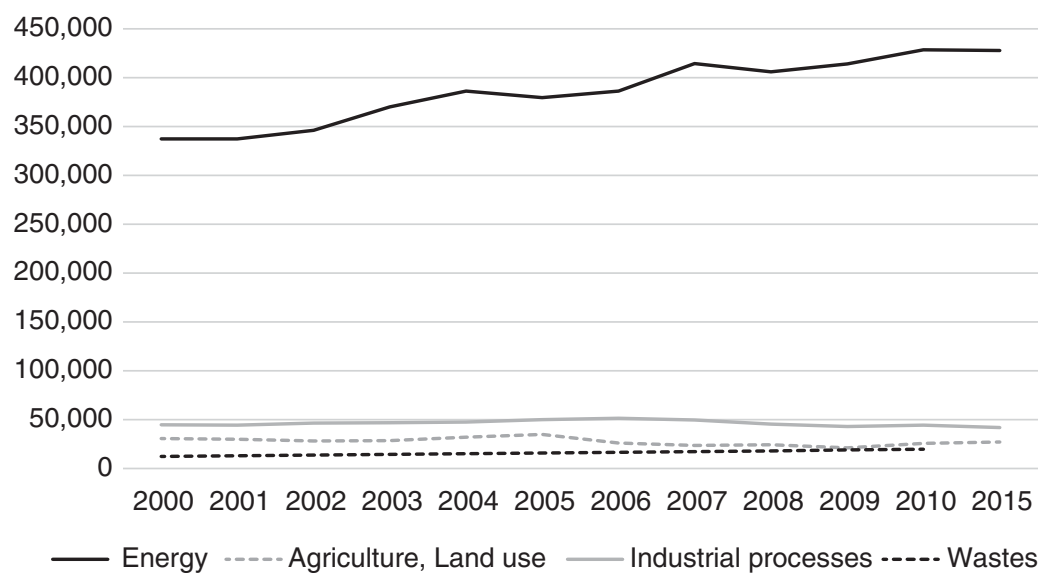

Figure 2.1 South African GHG emissions (Gg $\mathrm{CO}_{2}$ eq) by sector, 2000-2010, 2015

Source: Department of Environmental Affairs 2014: Appendix A, online at ht tp://unfccc.int/resource/docs/natc/zafnir1.pdf. One Gg is a metric kiloton. Updated for 2015 by Republic of South Africa (2018: 67-68).

Treasury and the Department of Energy, which is divided on renewable energy and climate change. These have struggled to develop the capacity needed to both formulate and implement climate policies. Global climate negotiations also enter the story, pushing South Africa to consider climate action when it might not have done so otherwise.

\subsubsection{Early Developments and Actors}

The early phases of global negotiations on climate change coincided with South Africa's transition away from an apartheid system in 1994. South Africa opted out of mandatory action in the Kyoto Protocol phase so that it could address its post-apartheid priorities: "the alleviation of poverty; the provision of basic services for all South Africans; equity; employment creation; and economic growth" (Government of South Africa 2000: viii). The post-apartheid government had little capacity to take environmental action of any kind. A new national Department of Environmental Affairs and Tourism (DEAT), created in 1994, spent its early years writing basic environmental legislation. The National Environmental Management Act of 1998 does not mention climate 
change or GHG emissions. ${ }^{3}$ Instead, the DEAT created a nonstate National Committee on Climate Change in 1996 to provide it with expertise it lacked on the subject (Chandrashekeran et al. 2017: 5-6).

External deadlines pushed the next developments in climate policy. South Africa wrote its first communication to the United Nations Framework Convention on Climate Change (UNFCCC) in 2004, as well as a National Climate Change Response Strategy (Vorster, Winkler, and Jooste 2011: 243-244). While ambitious in its aims, the Response Strategy included few implementing or monitoring instruments (Chandrashekeran et al. 2017: 6). The DEAT next prepared for new international demands for action by again drawing on external expertise, this time from the University of Cape Town's Energy Research Centre for a study of possible long-term mitigation scenarios (LTMSs) (Borland, Morrell, and Watson 2018: 58-59). ${ }^{4}$ The LTMS proposal to have GHG emissions peak by 2020, plateau for a decade, and subsequently decline was adopted as a governmental planning document in 2008 along with proposals for a new Carbon Disclosure project, a carbon tax, and an Energy Efficiency Accord (Upadhyaya 2016: 470; Vorster et al. 2011: 243-244; Winkler 2010). Despite this activity, there was considerably more planning than implementation. Achieving the scheduled peak, plateau, and decline of GHG emissions could be done only with cooperation from the electricity sector, which was proceeding on a very different track.

From 1922, Eskom had gradually concentrated control over electricity generation and distribution (Eberhard 2007: 215; Morris and Martin 2015). Eskom's near-monopoly of information and expertise in the electricity sector made it a formidable power, able to resist other agencies' planning directives. Another nonstate expert group had written an Energy White Paper in 1998, for example, that called for beginning the energy transition. The 2003 Renewable Energy White Paper told Eskom to have independent power producers (IPPs) build renewable energy plants, directives that it ignored until it was forced to adhere to them in 2011 (Eberhard 2007; Rennkamp et al. 2017:

3 www.gov.za/sites/default/files/a107-98.pdf.

4 Interview with Robert Scholes, Systems Ecologist with the Council for Scientific and Industrial Research (CSIR), Durban, 2011; interview with Harald Winkler, Energy Research Centre, University of Cape Town, Cape Town, 2011. Both participated in the LTMS studies. 
216). ${ }^{5}$ Even after a new Department of Energy moved to take planning functions from Eskom in 2009, the government had to return to Eskom to produce its Integrated Resource Plan (IRP) for 2010 since the modeling expertise simply was not available elsewhere. ${ }^{6}$ Eskom continued to play a major role in South Africa's delegations to the UN climate meetings, with an "undersourced" government asking for it to supply the technical side on anything related to electricity.

Eskom's capacity, in a literal sense, brought a turning point in this standoff. After fifteen years with minimal new electricity construction, it began building two large new coal power plants, Medupi in 2007 and Kusile in 2008. But Eskom was only breaking ground when electricity supply shortfalls started forcing scheduled electricity blackouts (loadshedding). Costs for both plants have nearly tripled while the time frames have already grown years beyond the original schedule. ${ }^{8}$ Repeated load-shedding, construction problems, and maintenance failures undermined Eskom's reputation as an actor that could manage the electricity sector and its perceived capacity. As an observer summarized, Eskom's leaders were no longer seen as "gods" (cited in Baker et al. 2014: 809). ${ }^{9}$

\subsubsection{The Years 2009 to 2011: A "Boom Cycle of Documents"}

Jacob Zuma challenged Thabo Mbeki for the presidency of the ANC and thus the country in 2009. When Zuma won, he changed the political landscape. Institutionally, he created a freestanding Department of Energy with new powers (2009) and paired environmental issues with water rather than tourism, briefly creating a Department of Water and Environmental Affairs (2010). By 2011, it was simply the Department of Environmental Affairs (DEA). ${ }^{10} \mathrm{He}$

5 Interview with Anton Eberhard, Professor at the Graduate School of Business, University of Cape Town, Cape Town, 2013. Eberhard participated in the expert committee that wrote the 1998 White Paper, as well as other activities.

6 Interview with Callie Fabricius, General Manager, Energy Planning and Market Development, Eskom, Germiston, 2014.

7 Interview with official at Eskom, Johannesburg, 2014.

8 www.fin24.com/Economy/Eskom/why-medupi-and-kusile-are-eskoms-achilles -heel-20160706.

9 Interviews with Eberhard 2013; Scholes, CSIR, 2011.

10 In 2019, the Department of Environmental Affairs became the Department of Environment, Forestry and Fisheries. For simplicity, this book refers to all these 
secured World Bank funding to complete Medupi and Kusile, even as his government initiated broader climate action discussions.

A multiday consultative Climate Change Summit brought many stakeholders together to debate future directions in March 2009. The Summit exposed significant divergence over what South Africans should do to address climate change, if anything. The main agreement was for more debate and consultation on key issues like electricity planning, the role of nuclear power, and a carbon tax. ${ }^{11}$ Given those disagreements, there was broad surprise when Zuma went to the UNFCCC's annual negotiation in Copenhagen at the end of 2009 and made an international promise for significant climate action. ${ }^{12}$ Although observers speculate that Zuma's decision was driven by his realization that South Africa's fellow large emerging powers - Brazil, China, and India - would be making commitments, he has never explained his sudden motivation for a significant pledge, which was not based on a national consensus in favor of climate action. ${ }^{13}$

These changes led to a set of developments in 2009-2011 that reset South Africa's climate agenda from stasis to action, creating what one activist called "a boom cycle of documents." 14 The Cabinet promptly endorsed Zuma's international commitment. It set up a National Committee on Climate Change, although key agencies like the Presidency, the Treasury, and the Department of Public Enterprises (DPE), which oversees Eskom, participated only sporadically, weakening it (Giordano et al. 2011: 32). The DEA led in drafting a Green Paper and then the National Climate Change Response White Paper of 2011, which translated the Copenhagen promises into sectoral strategies and

varying forms as the Department of Environmental Affairs (DEA), as this was its core function, although the book uses the full names for cited documents and interviews.

11 Foreword by Peter Lukey, Acting Deputy Director General: Climate Change of the Department of Environmental Affairs (Giordano, Hall, Gilder, and Parramon 2011). See also the parliamentary hearings on the eventual National Climate Change Response Green Paper at https://pmg.org.za/committeemeeting/12587/.

12 https://unfccc.int/files/meetings/cop_15/copenhagen_accord/application/pdf/so uthafricacphaccord_app2.pdf.

13 Interview with Eberhard 2013; interview with Mike Levington, Vice Chairperson South African Photovoltaic Industry Association (SAPVIA), Johannesburg, 2018; and other confidential interviews.

14 Skype interview with Melita Steele, Lead Climate and Energy Campaigner, Greenpeace Africa, 2014. 
programs for action for both adaptation and mitigation (Department of Environmental Affairs 2011).

\subsubsection{Efforts to Implement: The Department of Environmental Affairs as a Weak Center}

The Green and White Climate Papers proposed an implementation structure that put the DEA at the convening center of climate action. The DEA is a weak center, however, as it cannot do many of the actions required to reduce GHG emissions and address climate change impacts (Chandrashekeran et al. 2017: 7; Upadhyaya 2016). The DEA has had to manage its capacity gaps by mobilizing stronger links across the government and with civil society. ${ }^{15}$ Progress was slow and uneven after 2011 and often invisible beyond a small group of committed actors.

Even so, from 2014 to 2018, the DEA developed a Mitigation Potential Analysis (2014), National Atmospheric Emission Reporting Regulations (2015), an Air Quality Offsets Guideline (2016), a National Pollution Prevention Plan Regulation (second draft 2016), National GHG Emission Reporting Regulations (2017), a Declaration of GHG as Priority Air Pollutants (2017), and Climate Change Mitigation Policies and Measures (2017) before producing the first draft of a full Climate Change Bill in 2018. The DEA also wrote its first and second Annual Climate Change Reports for 2016 and 2017. Several of these use a "carbon budgets" approach that asks the minister of environmental affairs to set an overall national GHG emissions threshold and then parcel it out as a carbon budget to specified "persons" (including juridical persons, i.e., corporations) (Department of Environmental Affairs 2018). Sasol, a major industry emitter, has challenged the justification of this legislation in air pollution terms in the courts, leading the DEA to seek approval of the 2018 Climate Bill to strengthen the legal foundation of its work (Rennkamp 2019: 762).

The DEA produced two drafts of nearly all of these bills and regulations, seeking - and receiving - written comments from civil society groups, businesses, and other ministerial departments and other levels of government, as well as presenting the work orally to these groups and responding to comments and questions. This consultation was a huge and time-consuming task, but it was the only way to move

15 Interview, DEA official, Pretoria, 2014. 
beyond the limits on what the DEA itself could do. ${ }^{16}$ Many of these initiatives address the crippling lack of credible data on GHG emissions in South Africa. Even with the new regulations, data is being reported only on a voluntary and experimental basis until 2020 and requires developing reporting and analysis capacity for all participants (Trollip and Boulle 2017: 10-14).

\subsubsection{Civil Society: Principled and Self-Interested Actors Press for Life Beyond Coal}

The national climate debate has never been a mass discussion in South Africa. In fact, just 45 percent of South Africans agreed in 2015 that climate change is a very serious problem. ${ }^{17}$ Even so, there is a strong mobilized contingent among that minority of concerned South Africans. For them, the DEA has not moved nearly fast enough. Civil society actors began pushing for climate action when the new coal construction after 2007 brought an old economic model back to life. For several years, activists found climate action to be a unifying aim (Cock 2012: 25), drawing on "a relatively small group of dedicated individuals and organisations" to mobilize larger networks (Death 2014: 1225). Eighty organizations formed a coordinating committee for the 2011 climate negotiation session in Durban, organizing an alternative space for global NGOs and social movements, and convening a mass march of 12,000 people (Cock 2012: 25-26). This temporarily papered over some enduring divisions of both purposes and strategies, broadly characterizable as a fault line between a reformist green and an anti-capitalist red-green grouping of activists (Cock 2012: 26; Death 2014).

The more reformist green group is led by organizations like WWF South Africa, committed to serious climate action and interested in influencing and supporting state climate initiatives (Cock 2012: 28). While they are often critical of specific initiatives, this group also seeks opportunities to support governmental capacity in the sector where it can. Under various names, energy/electricity caucus groups have

16 Interview, DEA official, 2014. Comments from stakeholders that led into the 2018 Climate Bill draft are summarized in Department of Planning, Monitoring and Evaluation 2017.

17 www.pewglobal.org/2015/11/05/1-concern-about-climate-change-and-itsconsequences/. 
presented joint civil society positions in parliamentary hearings, commented on legislative projects and governmental energy plans, and held public discussions about South Africa's energy and climate options. ${ }^{18}$ Members of the caucus produce and commission technical analyses of climate and energy questions that they introduce into governmental and public debates (e.g., Fakir 2017; Teske and Lins 2011).

The red-green group is led by the EarthLife Africa and groundWork organizations that sometimes participate in energy caucus activities but also have ties to other organizations that are more critical of market solutions. Their social base has included not just labor organizations like the Congress of South African Trade Unions (COSATU) but also the "precariat," building on a strong environmental justice frame (Cock 2012: 25). This group has embraced strategies that are more challenging to the South African state's solutions to its energy and climate problems. EarthLife Africa and groundWork were instrumental in putting together a request for a World Bank Inspection Panel that found that the Bank had violated its own policies in approving the loan for Medupi in 2010 (World Bank Inspection Panel 2011). ${ }^{19}$ With the Centre for Environmental Rights (CER), they have followed a legal strategy to try to stop the government's coal-based energy agenda outright in their "Life After Coal" campaign. ${ }^{20}$ While the organizations in the Life After Coal campaign are active and have won some important legal cases that are discussed in Section 2.3, the broader redgreen coalition has disintegrated as the labor movement itself has fractured in the aftermath of the Durban negotiation in 2011 (Cock 2012: 26; see Chapter 3).

The Life After Coal campaign is a strong voice for just transitions for local communities that have historically hosted coal mines and electricity plants. Their analyses focus on the human costs of South Africa's energy choices, producing urgent studies like groundWork's blunt "Coal Kills" report (groundWork 2018; Centre for Environmental

18 See, for example, their comments on the process and substance of the draft 2018 Integrated Resource Plan hearings, at https://cer.org.za/news/concluding-thedraft-2018-irp-public-hearings-ngos-write-to-energy-committee. Interviews with Brenda Martin, Lead Organizer of the Energy Caucus and Director of Project 90x2030, Cape Town, 2013; Megan Euston-Brown, Sustainable Energy Africa, Cape Town, 2013; and Saliem Fakir, WWF South Africa, Cape Town, 2013.

19 Interview with Tristan Taylor, EarthLife Africa, Johannesburg, 2013.

20 Email interview with Nicole Loser, Attorney, CER, 2018. 
Rights 2017). Local communities have paid a heavy price in both environmental quality and local health and will now have few economic alternatives if coal leaves (Campbell, Nel, and Mphambukeli 2017; Naidoo 2015: 1050; Thompson 2018). The Life After Coal campaign is insistent that those dynamics must be addressed even as it also insists that coal mining end to address health, climate change, and other environmental impacts (groundWork 2018). ${ }^{21}$

\subsubsection{Private Sector: Hesitation without Open Blockage}

Not surprisingly, these climate action developments also galvanized the private sector, which became actively engaged in commenting on and trying to influence the developing policies after 2010. Alongside Eskom, South African businesses and industry associations have not openly mobilized against the country setting climate mitigation aims. Even the big producers of GHG emissions in the Energy Intensive Users Group (EIUG) are careful to stress that they recognize the need for South Africa to reduce its emissions. Their Industry Task Force on Climate Change (ITTCC) requires its members to accept the science of climate change. ${ }^{22}$ Commenting on a specific climate document, however, the ITTCC cautioned: "Business sees no reason for South Africa to have a legislative framework for climate change which is one of the most stringent in the world." 23

On the overarching framework, many firms are disturbed by what they see as a triple costing to them of climate action: they do not object per se to the DEA's idea of set carbon budgets, although they are keen to see them reflecting accurate data (Trollip and Boulle 2017). Most firms have gradually accepted wind and solar power, changes initiated through the Department of Energy. But they argue strongly against a carbon $\operatorname{tax}^{24}$ - the National Treasury also presented drafts of a Carbon Tax Bill in 2015 and 2017 - and they really object to having

21 Email interview with Loser, CER, 2018.

22 Interviews with Piet van Staden, EIUG, 2018; Jarradine Morris, EIUG spokesperson, Johannesburg, 2018; Kevin Morgan, CEO EIUG and Shaun Nel, spokesman EIUG, Johannesburg, 2014; and Eskom official, 2014.

23 Climate Change Legal Framework, http://ittcc.org.za/projects/. This page lists the joint industry response of some large industrial emitters to a number of proposed climate actions and informs this paragraph along with the interviews cited in Footnote 21.

Interviews with Morris, EIUG, 2018; Morgan and Nel, EIUG, 2014. 
all three of these mechanisms together, especially since they are being developed with only partial coordination by two departments and the Treasury (Rennkamp 2019).

Other ministries provided more positive incentives for climate action around the same time as the White and Green Papers, further muddling the business response. The Economic Development Department designed a New Growth Path in 2010 intended to help move the economy to a new greener economy. The accompanying National Infrastructure Plan and Green Economy Accord promised 300,000 new jobs related to clean infrastructure (Cock 2012: 22). The Department of Trade and Industry (DTI) and the DPE also wrote multiple Industrial Policy Action Plans and developed a renewable energy plan called the South African Renewables Initiative. The National Policy Commission added a broader National Development Plan that was released in 2012. It has a major chapter on sustainable development that calls for a just transition to a low-carbon economy, although the chapter fits awkwardly with other chapters that see a continued reliance on South Africa's traditional economy (National Planning Commission 2012). Finally, the program for contracting IPPs to build wind and solar power began in 2011 and won substantial praise (Eberhard, Kolker, and Leigland 2014). It is discussed in Section 2.3.

All of these initiatives together set a bewildering array of both positive economic incentives and new regulatory controls after 2009, all designed for some kind of climate emissions outcomes. The DEA has limited power to force coordination and policy integration is incomplete: the plans set different incentives and targets for different "green" outcomes, including wind and solar power generation, and the programs also include incentives for projects that are not green. Thus, the total result is less a specific climate mandate than it is indicative of the widening of the climate debate after Zuma's Copenhagen commitment and the inability of any single actor to lead the effort.

In summary, South Africa's coal-dominated status quo proponents have not tried to block national climate policies and institutions altogether. Especially between 2009 and 2011, numerous initiatives laid the foundations for climate action, with their acquiescence. The DEA proved a weak center for developing those foundations, despite pressure and inputs from civil society sectors seeking a just energy transition with different strategies. Eskom and its state and industry allies made limited responses to a confusing array of both state 
regulations and incentives for climate action. Yet while the theoretically expected status quo coalition did not fight against general climate policy, it used its power to take on the more specific question of whether climate plans would be translated into producing more wind and solar power, arguing increasingly strongly against.

\subsection{South Africa: Translating Climate Plans into Energy Choices}

South Africa can meet its climate goals only if it moves away from its coal-based energy system. That means building non-fossil fuel sources of electricity like wind and solar power and shutting down existing coal facilities at the end of their life cycle or even before, an existential threat to the existing sector. Historically, Eskom would have written any roadmap for energy transition, but the new Department of Energy took the electricity planning responsibility for itself in 2010. In particular, it was to produce an Integrated Resource Plan (IRP) with a binding build plan for electricity, to be updated biannually using new demand and cost data. The Department of Energy has only slowly accumulated the capacity to do so, leaving it highly vulnerable to pressures against renewable energy.

In this section, I trace the politics behind South Africa's IRPs: the officially adopted first plan for 2010-2030 (Department of Energy 2011) and the unadopted updates (Department of Energy 2013, 2016, 2017, 2018, 2019). As Figure 2.2 shows, the plans projected quite different levels of procurement of different fuel sources between 2010 and 2030. A dramatic planning story even at face value, it has turned out to connect to darker state capture dynamics (Chipkin and Swilling 2017).

The Department of Energy began working on the first IRP in 2010, but it had large gaps in both information and modeling capacity. The EIUG, which uses more than 40 percent of the national electricity supply, was very influential in the first IRP, especially on the quantity and nature of future electricity demand. ${ }^{25}$ The Department of Energy also had to return to Eskom for modeling and analysis skills. ${ }^{26}$ The 2010 IRP does lead off in new directions, following the Department of

25 Interview with van Staden, EIUG, 2018.

26 Interview with Fabricius, Eskom, 2014. 


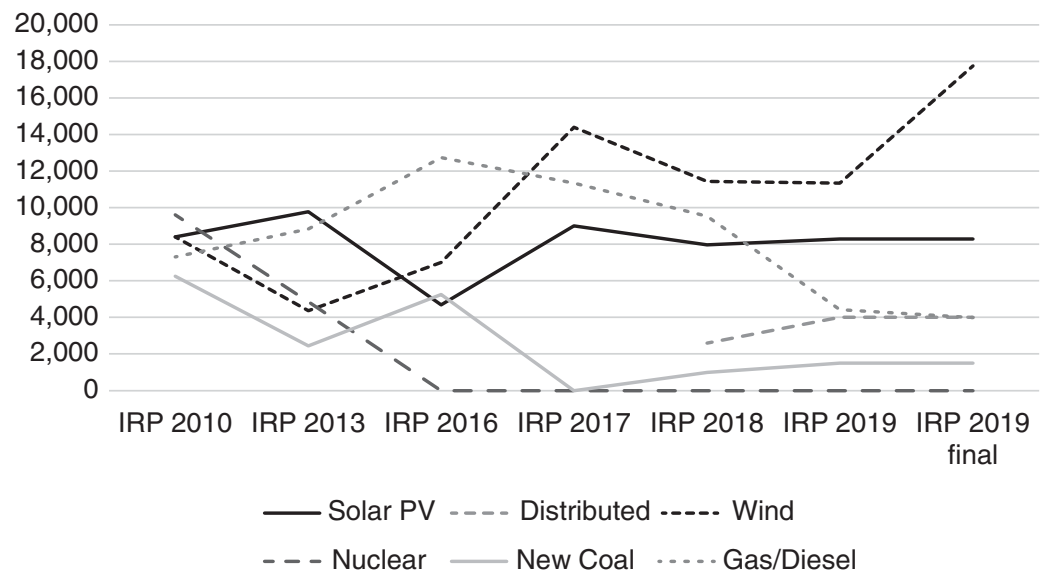

Figure 2.2 Projected total electricity procurement to 2030 by fuel type in drafts of the South African Integrated Resource Plan for Electricity Sources: Department of Energy 2011, 2013, 2016, 2017, 2018, 2019a, 2019 b.

Energy's directives to honor South Africa's new climate commitments while maintaining energy security and developing local industrial clusters. Since it assumes a GHG emissions constraint will come after 2024, it includes then-costly wind and solar power and proposes introducing them immediately in order to develop related industries and skills (Department of Energy 2011: 6-8). Industry and civil society made 5,090 comments on the IRP in 479 submissions, many on the cost of the various options and on whether nuclear power or renewables was the preferred noncarbon option. An early draft did not contain wind and solar in current build plans, but NGOs claim credit for having helped to put them in the final version. ${ }^{27}$ The final adopted IRP proposed 9.6 GW of new nuclear power by 2030, but it also included a 17.8 GW build of the wind and solar power that the planners saw as experimental. Coal had just $6.3 \mathrm{GW}$ of new build, although it was the fuel that both Eskom and the EIUG then trusted most as a source of baseload electricity. ${ }^{28}$

At the time of the first IRP in 2010, the question of how wind and solar power would be procured was still unsettled. The IRP itself assumed that it would be procured through a feed-in tariff and so discussed how the tariff might be set to avoid excessively high costs.

27 Interview with Robert Fischer, Project 90x2030, Cape Town, 2013.

28 Interviews with Fabricius, Eskom, 2014; Morris and Nel, EIUG, 2014. 
After load-shedding began in 2008, the National Energy Regulator (NERSA) had decided to use one of the tools in its portfolio to push renewable energy forward over Eskom's stalling. NERSA controls rates/tariffs, and it set up the Renewable Energy Feed-In Tariff (REFIT) in 2009 to promote renewable energy production in the private sector (Pegels 2014c: 130-131). The process served the purpose of drawing private investors to South Africa to put together proposed projects, but it was stymied by Eskom, which continued to refuse to sign agreements that would give the facilities access to the national grid. It was not clear that NERSA had the constitutional authority to create such a plan and neither the Department of Energy nor the Treasury supported it (Bode 2013: 73-74), ${ }^{29}$ but it was the existing framework at the time of the first IRP.

Given the legal impasse, competitors offered other procurement models. The South African Renewables Initiative (SARI) brought together a coalition of people who were interested in trying to attract new international climate funds to South Africa with individuals in the DPE and the DTI. SARI was launched during the 2011 Durban climate negotiations with European representatives who promised new climate finance for wind and solar power procurement; it was presented as one of South Africa's "Nationally Appropriate Mitigation Actions" (Upadhyaya 2016: 472). However, while internationally attractive, the coalition had not built ties early enough with the new Department of Energy, which developed its own program instead. ${ }^{30}$

The Department of Energy turned to the Treasury to help develop its plan, eventually named the Renewable Energy Independent Power Producers Procurement Programme (REIPPPP) (Eberhard et al. 2014). This program uses auctions to contract IPPs rather than the parastatal Eskom to produce electricity for the first time. Placing the semiautonomous program under the shield of the Treasury - necessary because the National Treasury had to guarantee the loans (Bode 2013: 73-74) - left room for a highly competent program officer to develop an island of efficiency that was beyond the Department of Energy's own capacity (Pegels 2014c: 139). The REIPPPP is often singled out as the one piece of South Africa's climate policy that has been effectively implemented (Rennkamp and Marquand 2018; Trollip and Boulle

29 Interview with Eberhard, Cape Town, 2013.

30 Interview with Fakir, WWF South Africa, 2013. 
2017). South Africa's submission to the Paris Agreement on Climate Change showcases it.

With the REIPPPP and a parallel program for coal IPPs in place, the second IRP had to be refined to reflect initial commitments of capacity to be built through these programs. The Cabinet had also agreed to produce nuclear power in some unspecified amount (Department of Energy 2013: 19). These promises vied with a clear slowing of demand as South Africa's economic growth stagnated and electricity prices rose, suggesting that less of all kinds of electricity would be built than originally contemplated. The original IRP had managed to appease competing constituencies in part through its plans to build electricity using all fuel sources. With less electricity needed, wind and solar power began to be more explicitly competitive with nuclear power as alternative ways to meet South Africa's climate obligations. In addition, Eskom had originally thought that it might build any renewable energy procured, ${ }^{31}$ but the new plans made it clear that IPPs would build them, threatening Eskom's monopoly on generation - which a nuclear build would retain.

The DEA's peak-plateau-decline scenario was officially integrated into this second IRP draft (Department of Energy 2013: 26). The new version of the IRP pleased no one as it placed artificial annual limits on wind and solar power and declared that the original plan's 9.6 GW of nuclear power might not be needed (Department of Energy 2013: 12). This set off a firestorm, with key ANC figures up to Zuma insisting on keeping nuclear in the mix. The new wind and solar industry associations joined civil society activists in pushing for wind and solar power without artificial limits instead. "Nuclear energy is the big zombie," said one. ${ }^{32}$ Long-standing community antinuclear activists joined the groups mobilized in response to the energy plans. ${ }^{33}$ Activists were also alarmed by the continuing coal build plans. Amid all the cross-currents, this IRP draft was never finished or approved. Even so, the Department of Energy announced that South Africa and Russia had signed an initial

31 Interview with Eskom official, 2014.

32 Interview with Taylor, EarthLife Africa, 2013; also, interviews with Johan van den Berg, CEO of South Africa Wind Energy Association (SAWEA), Johannesburg, 2014; Mike Levington, Vice Chairperson of South African Photovoltaic Industry Association (SAPVIA), Johannesburg, 2014; EustonBrown, Sustainable Energy Africa, 2013; Martin, Project 90 x 2030, 2013; Steele, Greenpeace, 2014.

33 Interview with Peter Becker, Koeberg Alert Alliance, Cape Town, 2013. 
framework agreement for nuclear procurement in September 2014. ${ }^{34}$ This agreement rested legally on the original IRP.

In 2016, another attempt to update the original IRP could not be finished in the context of a dramatically escalating debate over what kinds of electricity should be built. The first 2016 draft was just a sketch, showing cost curves for wind and solar power shifting down quickly, as bid prices dropped with South Africa's successive auction rounds (see Chapter 4). Nuclear prices and capital costs, meanwhile, were rising steadily, but the very first version had $25 \mathrm{GW}$ of nuclear. ${ }^{35}$ The subsequent public draft showed a least-cost scenario, instead, which called for larger quantities of wind and solar power while keeping annual build limits and new nuclear build only in 2037 and after (Department of Energy 2016: 26).

Activists and the renewable energy industries continued to push for a more serious climate response and more wind and solar power. ${ }^{36}$ The EIUG, by this time, had lost some of its skepticism of wind and power and become increasingly critical of nuclear power because it was so costly. ${ }^{37}$ A revised version of this plan, issued in November 2017, addressed some of these concerns. It showed that lower demand and changing comparative prices meant that no new coal beyond that already coming online or nuclear power should be built before 2030 . More detailed modeling of GHG emissions levels and climate policies also kept both coal and nuclear out until 2050 unless artificial annual limits on wind and solar power were imposed (Department of Energy 2017: 34).

Eskom and the Minister of Energy responded to the 2016 and 2017 drafts by strongly defending the nuclear program, arguing in parliamentary hearings that nuclear power should be built instead of renewable energy because it equally met South Africa's climate commitments while being no more expensive. ${ }^{38}$ Starting at the end of July 2016,

34 www.dailymaverick.co.za/article/2018-10-03-zuma-mahlobo-joematpetterssson-nkoana-mashabane-strong-armed-nene-into-signing-secret-russian -nuclear-deal/\#gsc.tab=0.

35 Interview with Levington, SAPVIA, 2018.

36 For an example of their comments, see the WWF comment on this $2016 \mathrm{draft}$ : http://dtnac4dfluyw8.cloudfront.net/downloads/WWF_South_Africa_inputs_o n_the_draft_Energy_and_Resource_Plans_Final.pdf.

37 Interview with van Staden, EIUG, 2018.

38 Hearing on 25 October 2016, at http://linkis.com/pmg.org.za/committee/ W9PMt. 
Eskom refused to sign final contracts for the twenty-seven wind and solar power projects selected in recent auction rounds (3.5 and 4.0) through the REIPPPP, arguing that the electricity was unneeded and too expensive. While the Department of Energy, the Treasury and even the Zuma administration expressed support for the REIPPPP, the contracts went unsigned until March 2018, after Zuma was pushed from office.

By 2016, the shadow story of state capture for nuclear power was becoming increasingly visible (Chipkin and Swilling 2017: 53-54, 64-66). The first pieces of the story actually date back to 2010, when Zuma's son Duduzane bought an unprofitable uranium mine with members of the Gupta family of businessmen. The expectation was that the mine would become profitable with the large nuclear build put into the first IRP and defended strongly by Zuma afterwards. Former finance minister Nhlanhla Nene testified to a parliamentary hearing in 2018 that, in July 2015, he refused to cosign a guarantee letter to the Russian government that South Africa would contract a nuclear program with it if the Russian government would fund it. Extensive Treasury modeling exercises had shown that the nuclear build was completely infeasible financially. ${ }^{39}$ Nene was fired in December 2015, hours after telling the Cabinet that nuclear energy was too expensive for South Africa to build (ibid.: 54). In a short period of time, South Africa had three finance ministers and five ministers of energy as the Zuma government struggled to keep its nuclear ambitions on track.

The nuclear part of the story was halted by some of the civil society actors already introduced. Once EarthLife Africa learned about a secret intergovernmental agreement on nuclear procurement with Russia in 2014, it joined with the Southern Africa Faith Communities' Environmental Institute to pursue a more activist strategy. ${ }^{40}$ Led by a group of mostly women, they held a weekly vigil outside parliament. While the organizations continued to oppose nuclear power on environmental and cost grounds, they also filed a court case on procedural

39 www.dailymaverick.co.za/article/2018-10-03-zuma-mahlobo-joematpetterssson-nkoana-mashabane-strong-armed-nene-into-signing-secret-russian -nuclear-deal/\#gsc.tab=0. Nene's complete testimony is available at www .scribd.com/document/390031857/Minister-of-Finance-s-Statement-at-theState-Capture-Inquiry\#download.

40 Their activities are described here: http://m.news24.com/news24/Opinions/INFOCUS/in-focus-i-meet-the-women-who-stopped-the-nuclear-deal-20170508. 
grounds of nonconsultation. Transparency groups like Right to Know and Open Democracy joined in the antinuclear activities along with unions, some twenty organizations in all. The court found on May 1, 2017 that the government's action was illegal and the procurement could not go forward without public consultation and parliamentary debate that would include fuller discussion of likely costs. ${ }^{41}$ That decision did not rule out nuclear power altogether, but it stalled what had been the Zuma administration's effort to pursue nuclear power quietly and quickly.

Another fight over coal broke out as the nuclear plans were being stopped. Successive IRPs continued to rely on coal, especially as supplied by new IPPs, and initial auctions even identified early winning bidders. At the same time, Eskom was scheduled to close five older coal plants as they reached the end of their normal lifespan. Most of the civil society groups already discussed strongly supported closing those plants and even accelerating other shutdowns, while arguing against new coal procurement whether from Eskom or the IPPs. They did so in comments on the IRPs as well as on the environmental impact assessments (EIAs) for specific plants, which also allow comments and challenges. A grassroots women's group called Women Building Power Campaign held its first energy and climate justice camp near the new Kusile coal plant in September 2018, in opposition both to the mines and the plants and to their exclusion from governmental decision-making. ${ }^{42}$

The Life After Coal campaign joined in these activities, but it also took the new coal projects to court. In the Thabametsi case, the court found that climate change needed to be assessed in the coal project EIAs, setting a precedent for further litigation and instigating another court challenge when the Thabametsi project was approved even after a subsequent EIA. Attorney Nicole Loser sees the court cases as successful in sending "a clear message of public opposition to unnecessary and dirty new coal plants." 43 The Campaign has also argued that the IRPs should be presented for stakeholder consultation in the communities where

41 http://earthlife.org.za/2017/04/nuclear-deal-blocked-judgement-made-on-thesouth-african-governments-secret-trillion-rand-nuclear-court-case/.

42 https://womin.org.za/images/WoMin_Newsletter_IssueSeptember_2018_Engli sh.pdf.

43 Interview with Loser, CER, 2018. The Thabametsi court documents are at htt ps://cer.org.za/wp-content/uploads/2017/03/Judgment-Earthlife-ThabametsiFinal-06-03-2017.pdf. 
electricity production actually takes place, locations where the Campaign plans to work for a just transition away from coal. ${ }^{44}$

Eskom began to fight increasingly hard to defend its own generation, beginning with the REIPPPP contract refusals in 2016. While Eskom has genuine corporate concerns about the shift in generation plans as generation is 60 percent of its revenues (Morris and Martin 2015: 35), its opposition was also related to state capture dynamics. The Public Protector wrote a complaint about efforts by then-CEO of Eskom Brian Molefe to use Eskom's procurement power to shift coal contracts to the same Gupta family and other cronies of the Zumas (Public Protector 2016; see also Chipkin and Swilling 2017). Parliamentary hearings have confirmed these and other accusations of corruption in Eskom's top politically linked management. ${ }^{45}$

To justify shifting the coal contracts, Eskom failed to make critical investments in its existing mines which then could not supply their contracted amounts. This led to the much more expensive trucking in of coal from new mines - and a new Coal Transporters Forum that added urgency to the labor demands with road-blocking strikes and a court case in 2017, asking that the REIPPPP contracts not be signed. ${ }^{46}$ Ironically, Eskom's mismanagement for these political purposes and the consequent added costs may have finally and most decisively squandered its capacity advantage in the energy sector, leaving it essentially bankrupt by 2018. Eskom's Chief Financial Officer has warned: "If we go down, we bring down the sovereign and the economy" since South Africa's national government has guaranteed Eskom's increasingly unpayable debt. ${ }^{47}$

In these debates, the position of unions has been especially complex. South Africa's unions repeatedly stress their commitment to significant climate action: "We were, and remain, absolutely clear that renewable energy is essential to mitigate climate change and that the RE [renewable energy] sector is not developing as fast as it needs to and that a socially owned and controlled sector can push its development far

44 Interview with Loser, CER, 2018.

45 www.parliament.gov.za/storage/app/media/Links/2018/November\%202018/2 8-11-2018/Final\%20Report\%20-\%20Eskom\%20Inquiry\%2028\%20NOV .pdf.

46 www.iol.co.za/business-report/energy/opinion-south-africas-energy-sectorneeds-a-transition-plan-10783292.

47 Eskom CFO Calib Cassim, at www.moneyweb.co.za/news/south-africa/wideranging-post-sona-interview-with-eskom-cfo/. 
faster than it is currently doing" (Cloete 2018: 4-5). ${ }^{48}$ The South African Federation on Trade Unions (SAFTU, a new trade union confederation created in 2017 by breakaway unions) agreed in a July 2018 conference that fossil fuels must be phased out while addressing working-class and workers' interests (Morgan and Domingo 2018: 13-14). Given the mix actually on offer in South African government policy wind and solar power, produced by private firms, with inadequate protection for coal workers and communities - the labor movement did not join the Life After Coal campaign in its court case, however. Instead, it joined an obscure group, Transform RSA, in legally challenging REIPPPP's wind and solar contracts and protested against the closing of coal plants (Cloete 2018). ${ }^{49}$ The labor movement's actions have picked the side of fossil fuels, notwithstanding its insistence that it stands with the other side in favor of climate action.

When Cyril Ramaphosa took the presidency and named new ministers in 2018, one of his first major policy decisions was to force Eskom to sign the REIPPPP contracts it had avoided. Another draft version of the IRP came a few months later, also showing that the balance of forces had returned to supporting wind and solar power. New Minister of Energy Jeff Radebe stated clearly that the "basic rationale" for building renewable energy was South Africa's international climate commitment, although he also drew a longer domestic time frame back to the 1998 White Paper on Energy Policy (Department of Minerals and Energy 1998). ${ }^{50}$ The first post-Zuma IRP was written without the participation of the EIUG and distributed in August 2018. ${ }^{51}$ The IRP had no new nuclear power in the period ending 2030 (Department of Energy 2018: 41). Its longer time coverage to 2050 even showed decommissioning of the small existing nuclear generation (ibid.: 49), although an amended version of this IRP in 2019 planned instead to extend the lifespan of the existing Koeberg station by twenty years (Department of Energy 2019a: 15). The 2018 IRP draft estimated that $200 \mathrm{MW}$ of distributed generation will be added

48 Karl Cloete is the National Union of Metalworkers of South Africa's (NUMSA) deputy general secretary and he is writing here in the SA Labour Bulletin.

49 http://saftu.org.za/renewable-energy-is-necessary-but-not-at-expense-of-jobssays-saftu/.

50 Media speech on February 24, 2019. Online at www.ee.co.za/article/the-statusof-electricity-generation-in-south-africa.html.

51 Interview with van Staden, EIUG, 2018. 
annually, and the next year's revision raised that to an estimated $500 \mathrm{MW} / y e a r$, acknowledging that consumers had moved ahead of policy regulating this (ibid.: 16).

The 2018 IRP draft noted yet another fall in demand and prioritized private electricity developers as generators over Eskom. It included the new coal contracted from IPPs, creating an excess supply of electricity and some gap years in solar and wind procurement (Department of Energy 2018: 41). Significant coal plant decommissioning - 12 GW by $2030,28 \mathrm{GW}$ by $2040,35 \mathrm{GW}$ by 2050 - would eventually bring down the share of coal in the electricity matrix, helping to meet climate goals and further sidelining Eskom's generation share. Coal's share would have dropped more quickly with no annual build limits for wind and solar power in the modeling (Department of Energy 2018: 11-12).

The 2018 and 2019 IRP drafts were not finalized on their original schedules and energy analyst Chris Yelland attributed the delay to the ongoing opposition of labor movements, who prefer more coal and nuclear production through Eskom than the draft contemplated. ${ }^{52}$ The 2019 amendment of this draft, responding to almost 6,000 comments including from labor unions, explicitly backed away from the question of whether Eskom or IPPs would build new electricity plants. Instead, it asserted a clear conclusion that least-cost considerations supported only solar, wind, and gas plants, whoever would build them (Department of Energy 2019a: 64, 82). Despite this, when yet another revised IRP was finally adopted in October 2019, small nuclear power and various kinds of "clean coal" had slipped back into the adopted version (Department of Energy 2019b: 11-12), while another 6,400 MW of wind power were also added (ibid.: 42). A strategy was to be developed that would allow Eskom to participate in building new capacity (ibid.: 17). These were the compromises that emerged in final discussions.

In its comments on the $2018 \mathrm{draft}$, Eskom corrected some factual information but largely agreed with the draft, a radical shift in position. ${ }^{53}$ Not surprisingly, the renewable energy industry sectors were again arguing for more and more regular wind and solar procurement, as the industries were already set back significantly by the two

52 www.ee.co.za/article/analysis-paralysis-over-south-africas-irp-for-electricitypresents-massive-economic-risk.html\#.XEAhtKTLeEc.

53 www.ee.co.za/wp-content/uploads/2018/12/Eskom-comments-to-DoE-onDraft-IRP-2018.pdf. 
years (2016-2018) when Eskom would not sign contracts. ${ }^{54}$ The energy and environmental NGOs sent a letter together in October 2018 demanding an urgent shift from fossil fuels to renewable energy, with no nuclear energy, and asking for a Just Transition plan that addresses the concerns of workers. They also asked for fuller consultation. ${ }^{55}$

The same paragraph (in all the post-2018 versions) mentions concerns for coal communities and workers after decommissioning but notes that there is no quantification of the full costs or socioeconomic impacts on them (Department of Energy 2019b: 44). The final version references the International Labour Organization's 2015 principles for a just transition and says that the multiple existing just transition initiatives should be brought together in one. ${ }^{56}$ The final version also makes an explicit choice to prioritize economic impacts and energy security over shutting down electricity plants that are not in compliance with environmental regulations (ibid.: 44); this leaves host communities of coal plants in poor environmental conditions and limits their prospects of a just transition. Researchers at Stellenbosch University, led by Michelle Cruywagen, have used national data to make a first estimation of just transition costs for sunsetting coal in South Africa, putting them at US\$360 million. ${ }^{57}$ Two-thirds of these costs are for rehabilitating the coal communities, while one-third are labor-related costs. ${ }^{58}$

In summary, electricity build plans proved to be the major site of contention targeted by the status quo coalition. The Department of Energy was now the central state actor (versus the DEA in broader climate policy), but it also lacked the capacity to both develop and push through its own preferred electricity build plans, even with support from the renewable energy industry and much of civil society. The powerful, if declining, state-controlled utility Eskom was able to wield many tools to block an energy transition through wind and solar

54 Interview with Levington, SAPVIA, 2018. See also the IRP itself, which summarizes comments received in Appendix D.

55 www.egsa.org.za/resources/climate-change/response-to-irp-public-hearingsand-expectations-for-the-irp-itself/.

56 www.ilo.org/wcmsp5/groups/public/—ed_emp/—emp_ent/documents/publica tion/wcms_432859.pdf.

57 Unless otherwise indicated, all currency numbers have been translated into approximate US dollar equivalents using historic currency conversion rates.

58 www.dailymaverick.co.za/article/2019-12-10-r6-billion-first-estimate-of-justtransition-in-south-africa/. 
power. This outcome fits with the theoretical expectation of the climate political economy that incumbent fossil fuel sectors will strongly resist their own obsolescence. That outcome was also reinforced by a less systematic factor, namely the Zuma administration's deep and corrupt commitment to building nuclear power instead. Together, they have strongly undermined the development of wind and solar power in South Africa, notwithstanding the country's climate action commitments.

\subsection{Brazilian Climate Capacity and Commitments}

In contrast to South Africa, Brazilian GHG emissions have come disproportionately from deforestation and land-use change. Annual rates of deforestation dropped substantially after 2005 before recently rising again (Figure 2.3). ${ }^{59}$ Most electricity has been generated through hydropower, usually lower in GHG emissions than fossil fuel plants (Barros et al. 2011). ${ }^{60}$ In the energy sector itself, however, GHG emissions have increased in Brazil almost every measured year. A major driver of these increases is the production and consumption of the petroleum fields discovered offshore in 2007 (Observatório do Clima 2018: 20), so Brazil also has an incumbent fossil fuel with powerful supporters, although it is mostly used in transport applications. ${ }^{61}$ These features have meant that much of the public debate about climate policy and implementation in Brazil has not been about electricity at all. The comparative success in controlling the major source of GHG emissions (deforestation) while economic growth continued also lowered the temperature of the debate and widened the coalition of supporters for a time before conflict flared again as agricultural interests pushed back after 2011 (Hochstetler and Viola 2012; Viola and Franchini 2018).

59 This discussion uses SEEG data compiled by Brazilian climate and energy NGOs from public sources. The SEEG data is reliable and more regularly updated, so used here.

60 Hydropower has historically been considered free of GHG emissions and the Brazilian government and many in the sector continue to agree (e.g., Tolmasquim 2016: 9). Empirical studies have found varying levels of emissions, particularly methane, in large tropical reservoirs, so many environmentalists question hydroelectric power on climate change grounds (e.g., Fearnside 2002).

61 Interview with André Ferreira, Instituto de Energia e Meio Ambiente (IEMA), São Paulo, 2018. Ferreira leads the energy analysis of SEEG. 




Figure 2.3 Brazilian greenhouse gas emissions ( $\left.\mathrm{Gg} \mathrm{CO}_{2} \mathrm{eq}\right)$ by sector, 1990-2018

Source: http://plataforma.seeg.eco.br/total_emission.

It is also straightforward to identify the actors on either side of a lowcarbon transition in Brazil, but they have much less to do with the electricity sector than in South Africa. One of the most active cleavages has been between the coalition of both principled and self-interested actors trying to stop deforestation and the agribusiness group that has concrete economic interests in turning forests into fields and grazing areas (Aamodt 2018). Much of the fight over Brazil's climate positions has been between them. In addition, Brazil discovered new deep-sea oil fields in 2007, creating another set of actors to resist turning away from fossil fuels. Without a strong fossil fuel presence in the electricity sector, it has remained largely outside the lines of contention. In fact, wind and solar power enjoy broad bipartisan support, even from President Bolsonaro who is committed to promoting economic growth over environmental protection in the Amazon and elsewhere. This section outlines how Brazil's climate action capacity has developed in this quite different context.

\subsubsection{Early Developments and Actors}

Brazilian state capacity in the environmental area began earlier and has reached farther than that in South Africa. Brazil's first national 
environmental agency was created in 1973 and grew rapidly. Environmental framework legislation was written in 1981 and an environmental ministry followed in 1985 (Hochstetler and Keck 2007). State-level environmental agencies made big gains in controlling pollution in the 1980 s, even as deforestation rose steadily after the 1970s, gaining ever more national and international attention with minimal effects. Brazil chose to host the UN Conference on Environment and Development (UNCED) in 1992 despite being a climate and biodiversity villain due to its inability and unwillingness to gain control over its Amazon region (Hochstetler and Keck 2007; Viola and Franchini 2018).

The Ministry of Science and Technology (MCT) was the first agency to take on climate change for Brazil, gaining the responsibility in 1994. Much of its agenda was internationally focused, helping the Foreign Ministry Itamaraty to develop its climate positions in the negotiations for the UNFCCC, launched at the 1992 conference. The MCT was instrumental in developing global agreements that exempted Brazil from immediate international obligations for climate action, like the idea of Common but Differentiated Responsibilities and the Kyoto Protocol that reserved climate action for developed countries (Lisboa 2002). With the Foreign Ministry, the MCT continues to advocate for the claim that the historical responsibility of developed countries for GHG emissions should make them the first and still primary actors to take on responsibility for reducing emissions (Carvalho 2012; Viola and Franchini 2018: 78-79, 152). Even so, the MCT oversaw the first Brazilian reports on its climate actions and developed systems for collecting and reporting data on its GHG emissions. ${ }^{62}$ It presided over early widening of climate policy discussions to include other ministries in the Inter-ministerial Commission on Climate Change of 1999 and the Brazilian Forum on Climate Change, created in 2000 to bring the private sector and civil society into the debate.

\subsubsection{Conquering Deforestation and Building Climate Capacity and Commitments}

The profile of the Ministry of Environment in climate politics began to rise in 2003, when Marina Silva became president Lula da Silva's (no

62 Sirene.mcti.gov.br, to become sirene.mctic.gov.br. 
relation) first minister of environment in the Workers' Party's (PT's) first national administration. As a former PT Senate leader with personal origins in an Amazonian rubber-tapper family, she had both partisan and activist credibility that allowed her to play a larger role than previous ministers had in this comparatively weak ministry (Hochstetler 2017). Silva's profile rose with her administration's unprecedented ability to bring deforestation - the country's largest source of GHG emissions - under control (see Figure 2.3).

The story of how Brazil's deforestation was controlled, especially in the Amazon region, is complex and beyond the scope of this book. Scholars have identified a number of simultaneous developments. These include new command and control programs of the Ministry of Environment itself like the Plan for Action to Prevent and Control Deforestation in the Legal Amazon (PPCDAm), stronger satellite monitoring, and demarcation of new protected areas (Carvalho 2012: 157; Schwartzman, Moutinho, and Hamburg 2012; Viola and Franchini 2018). They also include private governance initiatives for the soy and beef farming that spurred deforestation (Viola and Franchini 2018: 108-109; Waroux et al. 2019). ${ }^{63}$ For Silva's executive secretary, João Paulo Capobianco, the most important result of all these individual developments was to create a sense among potential deforesters that the state was present in the region and observing their behaviors for the first time, a sense that has declined since revisions to the Forest Code in 2012. ${ }^{64}$

Silva drew on the expertise of Brazilian civil society both to populate her ministry and as additional, sometimes critical, supports from outside the government (Aamodt 2018; Nasser de Oliveira 2015; Observatório do Clima 2008; Oliveira 2016). Environmental and human rights activists, including Capobianco himself, held 38 percent of her leadership positions (Abers and Oliveira 2015: 10). These activists, insiders and outsiders, were especially important in helping to redefine deforestation as a climate change issue.

As the global climate negotiations began to demand more efforts from large developing countries like Brazil after 2007, the issue moved

63 Additional studies question the results of some of these programs, especially as deforestation rates have crept up since 2012 (e.g., Gibbs et al. 2016; Gibbs et al. 2015; Richards, Arima, VanWey, Cohn, and Bhattarai 2017).

64 Interview with João Paulo Capobianco, former executive secretary of the Ministry of Environment, São Paulo, 2018. 
up the domestic political agenda. The presidency began a more active role in Lula's second term, overseeing the writing of a National Plan on Climate Change and presiding over a new Inter-ministerial Committee on Climate Change that would oversee it. The Ministry of Environment would now be its executive, with eight other ministries and the Forum, while the MCT continued to coordinate the technical side (Schaeffer et al. 2015: 8-9). Silva had clashed many times with Lula's government in his first term and the two took time to negotiate her participation as minister in his second term. Lula wanted Silva to take on the climate role because of international acclamation for her success in deforestation and she wanted his support for a ministerial reorganization and strengthening (Oliveira 2016).

The two preferences coincided in a new Secretariat of Climate Change and Environmental Quality in the Ministry of Environment in 2007. Its first secretary was Thelma Krug, who had helped develop Brazil's remote sensing systems for monitoring deforestation and later became vice-chair of the IPCC. Silva also oversaw the creation of a professional environmental career path. While no new positions in the Ministry of Environment were advertised from 1995 to 2002, leaving only occupants with short-term contracts, Silva hired 1,474 specialists in her 5 years through public competitions (Abers and Oliveira 2015: 17). These career positions are especially important for maintaining the ministry's activities even when elected politicians are less interested in climate action, as has been the case since $2011 .^{65}$ New resources accompanied the changes, including almost US $\$ 1.3$ billion donated by Germany, Norway, and Petrobras to an Amazon Fund for deforestation efforts that has been administered by Brazil's National Economic and Social Development Bank (BNDES) (Carvalho 2012: 159). ${ }^{66}$ Remarkable capacity improvements thus accompanied the new administrative home for climate change.

There is no question that this new state capacity was an important part of the story of Brazilian climate action, especially the improvements in its deforestation tallies. At the same time, the final push for climate action depended on widening the climate debate beyond just government bureaucracies and environmental movements, a process that both made climate action commitments possible and also set the

65 Interview with Capobianco, MMA, Brasília, 2018.

66 www.fundoamazonia.gov.br/en/donations/. 
stage for subsequent decline. After 2007, a growing number of actors signed on to support climate change. These included those with instrumental commitments to climate action, like the Amazonian governors who saw possible international funds for forest protection and coalitions of industrialists who worried that there might be restrictions on their exports if they failed to push Brazilian climate action forward (Hochstetler and Viola 2012).

When Marina Silva left her position and then decided to run for president in the 2010 election, climate action became a central focus of electoral politics. The Brazilian population is broadly supportive of climate action, with 86 percent agreeing that it is an important issue. ${ }^{67}$ All three major presidential candidates went to the 2009 climate negotiation in Copenhagen and competed with each other to support climate action. It was in this atmosphere that Brazil made its first voluntary commitment to international climate action in 2009. It also passed a comprehensive climate law at the beginning of 2010, although Lula did veto the clauses that promised a move away from fossil fuel production under pressure from the Ministry of Mines and Energy (Aamodt 2018: 15). The unprecedented gains in controlling deforestation underpinned both commitments. Important parts of climate action have evident multiparty support in Brazil, like this climate legislation which was supported by all major parties.

\subsubsection{Retreats and Gains in Climate Policy Implementation after 2010}

The political consensus behind climate action was never complete. A caucus of agriculturalists and others with an interest in deforestation began to gain strength and political power in the National Congress after 2003, trying to roll back EIA, indigenous rights, and the 1996 Forest Code with its strict limits on deforestation on private land. After the 2010 election, they had the power to force through a revised Forest Code in 2012, over the objection of environmentalists, the Senate, and the executive (Viola and Franchini 2018: 140-141). Business leaders slipped from sight as it became clear that the United States would not take climate action (Viola and Franchini 2018: 161). In general, the

67 www.pewglobal.org/2015/11/05/1-concern-about-climate-change-and-itsconsequences/. 
next years were overwhelmed by larger political phenomena like economic recession, a huge corruption scandal, the controversial impeachment of Lula's copartisan Dilma Rousseff, and the eventual election in 2018 of a new president, Jair Bolsonaro.

Bolsonaro represented a break with not just Brazil's two leading parties but many of the foundations of Brazilian politics, too. His environmental agenda looks very much like that of the agriculturalists (Vialli 2018). His influential sons, also politicians, are even climate change deniers, previously a rarity in Brazil. ${ }^{68}$ As they provide active political leadership against climate action for the first time, the thinness of popular commitment to it has become clearer. With a political system that is increasingly divided between supporters and critics of the PT, the anti-PT position is linked to being against climate action. ${ }^{69}$ Nonetheless, the only positive promise that the Bolsonaro campaign made for environmental governance was to continue Brazil's renewable energy programs (Vialli 2018), suggesting that this is a rare pocket of policy consensus.

At the same time, smaller-scale changes set up both advances and retreats on climate policy. Under Rousseff and her replacement, her vice president Michel Temer, environmental budgets were already cut drastically after 2013 (Hochstetler 2017; SEEG 2018a: 48; Viola and Franchini 2018: 140). Such budget cuts undermined the capacity improvements that came earlier. Rousseff's Minister of Environment, Izabella Teixeira, was technically respected internationally but had few links to environmentalists and was perceived as following Rousseff's pro-growth strategy without questions. Rousseff favored the petroleum sector and other big development projects central to the corruption scandal (Arruda de Almeida and Zagaris 2015; Hochstetler 2017). The Temer and Bolsonaro governments are more committed to market forces and austerity, but they follow Rousseff in having little positive agenda for environmental protection. Deforestation has climbed back up to a point where Brazil's ability to meet its 2020 commitments is in question. ${ }^{70}$

68 www1.folha.uol.com.br/ambiente/2018/11/hostilidade-de-filhos-de-bolsonaro -a-aquecimento-global-preocupa-ambientalistas.shtml.

69 Interview with Andre Nahur, Coordinator Climate Change and Energy, WWF, Brasilia, 2018.

70 Interview with Capobianco, MMA, 2018. 
Meanwhile, the Ministry of Environment has overseen steps toward implementing the climate commitments. Decree 7390/2010 wrote the first five action plans for implementation, including energy plans that placed the Ministry of Energy's planning processes at the center (see Section 2.5). Some clauses like the proposed carbon tax proved too difficult to negotiate, but other proposals like adaptation measures moved quickly and became part of Brazil's Nationally Determined Contribution to the Paris Agreement. ${ }^{71}$ After a significant lull in 2015-2016 when few parts of Brazil's climate policy infrastructure were operating, a coalition of business and civil society actors came together to reactivate the Brazilian Forum on Climate Change, forming eleven technical bodies that formulated proposals for climate implementation to give to the 2018 presidential candidates (SEEG 2018a: 48 ), as they had done in 2014. The group did succeed in getting the Paris Agreement ratified in 2017 (Instituto Clima e Sociedade 2018). Brazil's closest equivalent to South Africa's EIUG of big industrial consumers has not prioritized climate and renewable energy, although some of its members do. ${ }^{72}$ Yet sixty large businesses, whose revenues equal about 45 percent of the national GDP, have rejoined the Brazilian Business Council for Sustainable Development (CEBDS) and helped develop the set of ten recommendations for the 2018 presidential candidates. Four of their proposals addressed the electricity sector, urging the government to exceed its Paris promises to have 45 percent renewable energy, including wind and solar, in the energy system (CEBDS 2018: 13).

The dominant role of deforestation in Brazil's GHG emissions profile has created a very different politics of climate action there. It has been highly contentious, more so than in South Africa, but the contention has remained largely outside the electricity sector, which has little fossil fuel production. This set the possibility of more technically oriented electricity planning in the sector, which did appear, following the climate political economy logic. As Section 2.5 shows, however, that planning has so far favored wind power but not solar, suggesting that it is influenced by more than just climate motivation, which favors both.

71 Interview with Adriano Santhiago de Oliveira, Departamento de Mudanças Climáticas, MMA, Brasília, 2014.

72 Interview with Victor Hugo Iocca, Coordinator of Electric Energy, Associação Brasileiro de Grandes Consumidoras Industriais e de Consumidores Livres (ABRACE), Brasília, 2018. 


\subsection{Brazil: Translating Climate Plans into Energy Choices}

In the 1990s, the Cardoso government partially privatized the electricity sector, taking electricity planning from the parastatal Eletrobras in favor of private, market-driven investment (see Chapter 3). Multiple economic and fiscal crises meant that there was essentially no new capacity built in the sector in the 1990s. When a severe drought brought the electricity system into its own crisis in 2001, widespread blackouts set the stage for the first wind procurement in 2002, through the Program of Incentives for Alternative Energy in Electricity (Proinfa). The timing of the introduction of alternative renewables into the electricity grid thus reflected the need to reduce the system's overreliance on large hydro, an energy security concern. ${ }^{73}$ Proinfa was a product of the energy bureaucracy, preceding broader public debate.

In the Cardoso version (Law 10,438/2002), the program invited independent power producers to provide 1,100 $\mathrm{MW}$ each of wind, small hydro, and biomass-based electricity to the system, responding to a feed-in tariff guaranteed for twenty years. In a second phase, nonhydro renewable energy was to reach 10 percent of national electricity consumption by $2022 .{ }^{74}$ The incoming PT government (20032010) amended the law the next year (Law 10,762/03), keeping the initial tranche but introducing an auction system for the second stage (Lucas, Ferroukhi, and Hawila 2013; Tolmasquim 2012). In this system, the electricity regulator ANEEL holds periodic auctions where the hundreds of electricity generators in the country can bid to supply electricity under long-term, fixed price contracts. Some reserve auctions are only for particular kinds of electricity while others allow different types to compete against each other with different caps in price for each type. The continuity of Proinfa across the administrative handoff shows again that nonhydro renewables have been largely a nonpartisan issue in Brazil.

Lula did recreate state electricity planning after a hiatus of almost a decade. The Ministry of Mines and Energy gained the Energy

73 Interview with Elbia Melo (now Gannoum), Chief Executive Officer of the Brazilian Wind Energy Association (ABEEólica, Associação Brasileira de Energia Eólica), São Paulo, 2014. J. Ricardo Tranjan conducted this interview for the book, along with others that are identified in footnotes by his initials (JRT). Gannoum was then chief economist in the Ministry of Mines and Energy and conducted the analyses showing the feasibility of the Proinfa program.

74 www.planalto.gov.br/ccivil_03/leis/2002/L10438.htm. 
Research Enterprise (EPE) in 2004, which carries out long-term indicative planning for the sector (e.g., Empresa de Pesquisa Energética 2014b). Despite the break in planning, EPE was able to put together a high-capacity and good-sized bureaucracy quickly, with most employees hired following civil service exams. The bureaucracy has strong technical skills, using optimization analyses to generate complex grid expansion plans based on criteria that include site and economic data, forecasts of future demand, a preference for low-carbon options, and other criteria. ${ }^{75}$

These result in annual recommendations of the amounts of different kinds of electricity that should be procured and lists of possible locations and projects. They also recommend price ceiling levels for the auctions based on economic analyses. The reports are dense with justifications and supplemental analyses and can run over 800 pages each. ${ }^{76}$ The Ministry of Mines and Energy then plans specific auctions each year, also consulting with the electricity regulator ANEEL, and EPE sets maximum prices (Bradshaw 2018: 94). These processes are all overseen by the National Council on Energy Policy (CNPE), created in 1997 (Law 9478) and presided over by the Minister of Mines and Energy. It can make both overarching and detailed changes in national energy plans, but the vast majority of its interventions are in the oil and gas sector, not electricity. ${ }^{77}$

EPE's ten-year planning documents are produced almost every year, with occasional thirty-year plans. They see little of the drama of the South African IRP even though drafts are also presented for discussion and comment. The one exception is in the area of hydropower, where EPE technocrats were surprised when environmental activists mobilized strongly against their first plan that showed that water resources would allow forty more large hydroelectric dams, mostly in the Amazon region (Empresa de Pesquisa Energética 2006: 281). From EPE's point of view, it was only a technical statement about what physically could be built, ${ }^{78}$ but the listing has been taken as a signal

75 Interviews with Ricardo Cavalcante Furtado, Superintendent of Environment, Empresa de Pesquisa Energêtica, Rio de Janeiro, 2009 and a technical consultant, Empresa de Pesquisa Energética, Rio de Janeiro, 2012.

76 They are readily available online at www.epe.gov.br/pt/publicacoes-dadosabertos/publicacoes/plano-decenal-de-expansao-de-energia-pde.

77 See the resolutions listed at www.mme.gov.br/web/guest/conselhos-e-comites/ cnpe.

78 Interview with Furtado, EPE, 2009. 
of governmental intentions and helped to mobilize a large coalition of national and international actors against large hydropower in the Amazon (Bratman 2014; Hochstetler and Tranjan 2016; Zhouri and Valencio 2014). In addition to pressuring the government, activists have also targeted the firms, banks, and institutional investors involved (e.g., Greenpeace 2016a). The Movement of those Affected by Dams (MAB) leads a more openly critical group of social movements and labor organizations in the Labor and Peasant Energy Forum (POCE) that wants to end the entire private concession system along with large hydropower (Just Transition Research Collaborative 2018: 17-18). ${ }^{79}$ The mobilized opposition to hydropower has been mentioned in numerous planning documents as a limit on Brazil's electricity choices (e.g., Tolmasquim 2016: 123-126).

Beyond hydropower, there has been much less attention to the plans, which remain largely technical documents for bureaucratic audiences. While comments are invited on drafts, they do not typically change the documents although industry lobbies and political actors may influence outcomes. ${ }^{80}$ Even so, a cluster of NGOs in the Climate Observatory (Observatório do Clima), a Working Group on Infrastructure and Energy (GT Infraestructura e Energia), and a Front for a New Energy Policy (Frente por Uma Nova Política Energética) individually and collectively comment on EPE's plans and have positioned themselves as strong supporters of more wind and solar power as well as pressuring from outside governmental processes. ${ }^{81}$ Some NGOs, like the Institute of Energy and Environment (IEMA) and WWF-Brasil have contributed numerous studies that aim to provide a technical basis for environmentally sound energy choices (e.g., WWF-Brasil 2015a, 2015b). ${ }^{82}$ Unlike the anti-hydro activists, these are more accepting of the basic framework of the energy system, even as they work to improve its choices. Some organizations like Greenpeace Brasil span the two types. Civil society engaged EPE more directly starting in 2016, when the Climate and Society Institute (Instituto Clima e Sociedade)

79 Interview with Gilberto Cervinski, Member of the National Coordination of the MAB (JRT), São Paulo, 2013.

80 Interviews with energy analyst, EPE, Rio de Janeiro, 2014 and EPE technical consultant, 2012.

81 Interviews with Marcelo Lima, Energy Campaigner, Greenpeace-Brasil, São Paulo, 2018; Ferreira, IEMA, 2018; Nahur, WWF-Brasil, 2018.

82 http://energiaeambiente.org.br/produto_tipo/publicacoes. 
organized a series of events that brought EPE's analysts together with civil society and business to discuss the climate-energy nexus (Instituto Clima e Sociedade 2017). ${ }^{83}$

Businesses themselves are not united on what kind of electricity to build and the importance of climate change in the choices. The Brazilian Association of Large Industrial Energy Consumers and Free Consumers (ABRACE) focuses strongly on price issues, clearly placing them above climate concerns, which it does not mention in public statements on energy policy. ${ }^{84}$ As already discussed, sixty of the largest Brazilian businesses in the Leaders Council of the Brazilian Business Council for Sustainable Development (CEBDS) are quite a bit more in favor of climate action and increasing renewable energy, including wind and solar power (CEBDS 2018). The wind and solar power industry associations also frequently cite the climate benefits of their industries.

EPE's plans have sometimes been outweighed by economic crisis responses from the rest of the government, as when the National Council on Energy Policy canceled an expected auction for wind and solar power in 2016 when demand lagged, without any consultation or warning (Bradshaw 2018: 112). While responding to the 2008 global financial crisis, the Lula government also allowed municipalities and states to propose their own shovel-ready energy projects for inclusion in the Program for Growth Acceleration (PAC) (Burrier 2016), to the dismay of EPE's analysts. ${ }^{85}$

Looking at the planning documents themselves to see how they reflect climate concerns, the very first one makes only a single general reference to international climate agreements (Ministério de Minas e Energia 2006: 241). Subsequent plans spend increasing amounts of time discussing the greenhouse effect and climate policies. The IPCC's Fourth Assessment Report inspired EPE to begin including GHG emissions in its optimization models in 2007 (Ministério de Minas e Energia 2007: 55) and to begin using IPCC methodology in 2010 (Ministério de Minas e Energia 2010: 318). Starting in 2011, EPE, through meetings of the Brazilian Forum on Climate Change, acknowledged that its ten-

83 www.icv.org.br/2017/05/organizacoes-socioambientais-abrem-espaco-dedialogo-com-epe-para-discutir-planejamento-da-matriz-eletrica.

84 For example, abrace.org.br/2018/01.26/corajosas-arrojadas-e-desafiantes. Interview with Iocca.

85 Interview with EPE consultant 2012; interview with Celso Knijnik, Director of the Energy Program of the PAC, Ministério de Planejamento, Brasília, 2014. 
year plans need to help Brazil meet the specific commitments the country made in Copenhagen (Ministério de Minas e Energia 2011: 283) and later in Paris.

At the same time, the organization uniformly insists that Brazil's dependence on hydropower means that it does not need to decarbonize its electricity sector; it is already one of the cleanest in the world (Tolmasquim 2016). ${ }^{86}$ Thus, EPE's primary arguments for wind and solar power recognize them as low-carbon sources and increasingly a substitute for hydropower with its nonclimate social and environmental problems, but that was not the primary motivator for bringing either into the grid. In fact, there is no good climate change rationale for procuring lots of wind power and very little solar power, as Brazil did until 2017. A climate rationale would seek both.

Wind power originally found a place in the grid plans as a comparatively cheap and quick way to diversify the matrix and provide energy security (Ministério de Minas e Energia 2006: 77). As Figure 2.4 shows, EPE's models were originally quite conservative on wind power, projecting nearly flat procurement totals over the next decade with just Proinfa's low levels. But the modeled procurement levels, which always begin with the real current-year totals, began to rise quickly in every year in the plans produced from 2009 to 2018. The turning point was in the 2010 plan, after the winning bids to build wind power in the first auction in 2009 were very competitive versus other fuel sources, "against all market predictions" (Ministério de Minas e Energia 2010: 57). From then on, EPE considered wind to be a climate-friendly substitute for hydropower.

EPE noted in 2010 that it did not plan to contract more fossil fuel plants beyond those already auctioned and being constructed, now that wind and other renewables had shown themselves to be "adequate and appropriate," including on price (Ministério de Minas e Energia 2010: 77). This decision showed up in subsequent planning for fossil fuels in the electricity sector, as seen in the leveling off in Figure 2.5. The rise of

86 EPE does not accept the contention by some activists and scholars that Brazilian hydropower has high GHG emissions in the form of gases leaking from reservoirs. Instead, EPE draws on its own and other studies that concluded that only the Balbina dam had GHG emissions higher than those of fossil fuel plants and that better design can lower the emissions (Ministério de Minas e Energia 2007: 437-438). That is not the same as saying that they have no emissions, but it has satisfied EPE (Tolmasquim 2016: 112). 


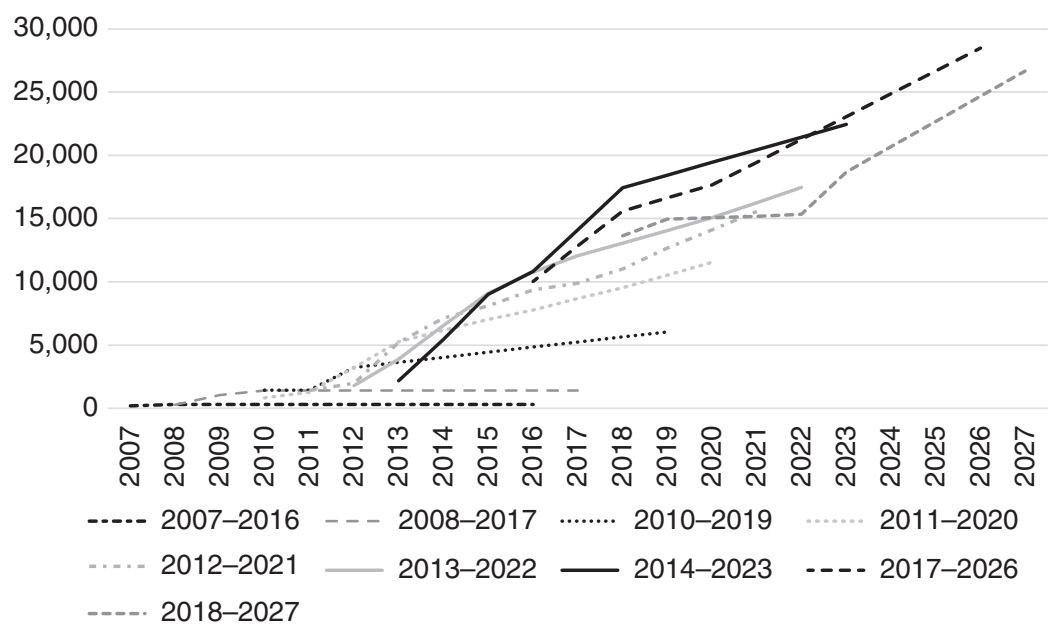

Figure 2.4 Wind power total procurement projections in successive 10-year plans in Brazil, 2007-2018

Source: Calculated from data in Ministério de Minas e Energia, 2007-2018. Note : Starting points for each series are actual contracted/built quantities for that year.

fossil fuel sources in the electricity matrix after the 2001 electricity crisis had alarmed activists and is one of the pieces of evidence often cited to illustrate Brazil's backward movement on climate implementation (e.g., Viola and Franchini 2018: 89-91).

However, the most significant increases in planned fossil fuel plants came in the $2018 \mathrm{draft}$, for the decade to 2027. This year's plan reflected a major change in electricity planning as the penetration of wind power was scheduled to reach 12 percent of the grid by 2027 with solar half that. Given the intermittency of these forms of electricity, EPE now planned a massive build-out of natural gas plants to complement the more variable new forms of electricity at peak times (Ministério de Minas e Energia 2018: 56) (Figure 2.5). The plan also indicated that Brazil would retire some dirtier oil and diesel plants, but the addition of so much natural gas - effectively replacing hydropower as a system stabilizer - will push GHG emissions up and risks other environmental impacts (Instituto de Energia e Meio Ambiente 2018a). The proposal has led energy and climate NGOs to prioritize finding an alternative to natural 




Figure 2.5 Fossil fuel projections in successive 10-year plans in Brazil, 2007-2018

Sources: Calculated from data in Ministério de Minas e Energia, 2007-2018.

gas and to resist the new gas, but a strong international and domestic oil and gas lobby favors the greater use of gas in its own right.

Solar power had been mostly omitted from the annual plans, without comment, except for some use in solar water heaters. This major tool for combating climate change was not attractive to planners, although the ten-year plan of 2012 noted that it would become desirable if global prices continued to drop (Ministério de Minas e Energia 2012: 90). Two years later, solar went into the build plan, with an auction scheduled in 2014 for delivery in 2017 and more growth afterwards (Ministério de Minas e Energia 2014: 90). Although nothing had changed about solar power except its price, it now was lauded for all of the good qualities of wind power, including its use as a substitute for fossil fuels. The delayed start showed that other logics - those covered in Chapters 3 and 4 of this book - had outweighed solar power's climate change virtues. Subsequent plans put solar power's rate of increase on the fast track that wind had followed (see Figure 2.6).

EPE manages the centralized part of the grid. It calculates expected aggregate demand and devises build plans to meet it. Meanwhile, however, the electricity regulator ANEEL wrote new distributed solar regulations in 2012 and more permissive ones in 2015, largely for nonclimate-related reasons. As these took hold, EPE's 2017 plan 


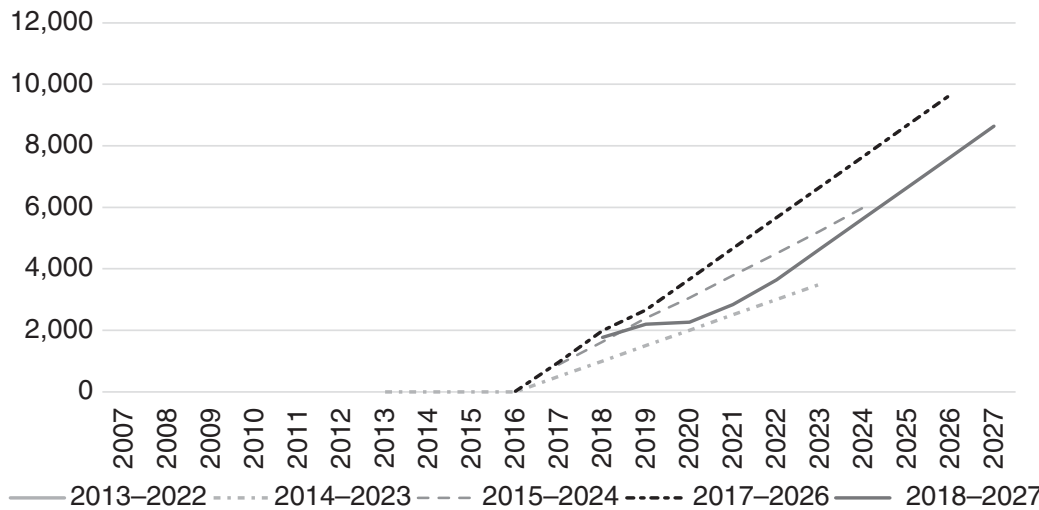

Figure 2.6 Grid-scale solar projections in successive 10-year plans in Brazil, 2007-2018

Sources: Calculated from data in Ministério de Minas e Energia, 2007-2018.

suddenly recognized the possibility of 770,000 distributed connections by 2026, mostly solar power (Ministério de Minas e Energia 2017: 221). This was a vertiginous increase after the 670 small generators counted in the previous plan (Ministério de Minas e Energia 2015: 373). After even faster take-up the next year, the 2018 plan anticipated 1.35 million adopters by 2027 , or 11.9 GW, or up to $21 \mathrm{GW}$ depending on the regulations chosen (Ministério de Minas e Energia 2018: 209). For EPE, this entered into its plans mostly as lower centralized demand. Almost all of these new distributed systems will be in urban areas, but, in remote regions, they may replace the diesel-based systems that currently mean that just 0.8 percent of the electricity supply generates 10 percent of its GHG emissions (Bezerra et al. 2017: 5). Since the rationale for distributed power in Brazil has been mostly price-based, all these points are discussed further in Chapter 4.

While decentralized solar power expanded on a largely nonclimate track, the increase in centralized solar power was especially quick after Brazil sent its Nationally Determined Contribution (NDC) document to the Paris Agreement. Solar power had to be forced into the procurement model as a policy choice in order to keep Brazil on track for its Paris pledge of keeping its GHG emissions 37 percent below the 2005 levels by 2025. EPE warned that emissions from electricity would then be at only 3 percent of Brazil's total emissions and the sector really 
could not do more to help Brazil meet its Paris pledge (Ministério de Minas e Energia 2018: 245).

As the final point suggests, Brazil continued to see high and growing GHG emissions in the energy sector, even as they were increasingly limited in the electricity sector itself. There is a kind of schizophrenia between EPE's careful parsing of the GHG implications of the electricity grid and the ways it fails to discuss and propose containing the freely growing emissions from oil production and use, grown to 57 percent of all energy and industrial process emissions in 2018 (SEEG 2018b: 2). The electricity and petroleum halves of the annual ten-year plans are strikingly distinct. While the press and activists have noted the GHG emissions from oil production, refining, and use, Petrobras itself has an optimistic discourse on carbon capture and storage and expresses certainty that environmental risks can be managed in the environmental licensing process - arguments readily accepted by its regulators and apparently EPE (Braathen 2015; Viglio, Di Giulio, and da Costa Ferreira 2017).

The most open debate on the petroleum has been about how oil and gas royalties would be distributed. A small portion originally went to a Social Fund that supported climate action among other things but was later mostly moved to health and education. Coastal producing communities depend heavily on royalty payouts even as the payments appear to have contributed to local resource curses and weaker development outcomes (Lima-de-Oliveira and Libby 2017). Brazil's major trade union, the Unified Workers' Confederation (CUT), attends the global climate negotiations and has participated in discussions of just transition internationally. ${ }^{87}$ Activists have brought little of the debate to Brazilian electricity except around hydropower (Just Transition Research Collaborative 2018: 17-18). Moving away from petroleum would present just transition challenges for oil workers and communities, but the debate is not far advanced in Brazil and has not been linked to wind and solar power at all.

Like coal in South Africa, oil production in Brazil is deeply embedded in the national political economy. Domestic oil production is about 12 percent of Brazilian GDP (Lima-de-Oliveira and Libby 2017: 577).

87 See, for example, www.cut.org.br/artigos/cop-22-movimento-sindical-avancano-debate-sobre-transicao-justa-apesar-de-conju-d2b6. 
The state-controlled oil company Petrobras received the single largest loans ever made by BNDES, over $\$ 13$ billion in just a few large loans and credit facilities in 2009 (Hochstetler and Montero 2012: 1492). A new suite of tax and regulatory incentives for fossil fuels was developed between 2013 and 2017, notwithstanding Brazil's climate commitments (INESC 2018).

In 2014, a giant corruption scandal was uncovered based on state contracting and construction with Petrobras and large hydro and nuclear power at its heart (Arruda de Almeida and Zagaris 2015; Jucá, Renno, and Melo 2016). Called the Lava Jato (car wash) scandal, it has been corrosive for Brazilian politics, involving numerous highranking politicians, and economically very costly for the firms involved and the economy as a whole. It is harder to see more specific impacts on wind and solar power than in the South African case, however. The electricity projects most clearly involved - the Belo Monte hydroelectric dam and the Angra 3 nuclear plant - dated back to the 1970s in conception and were both included in EPE's first ten-year plan (Ministério de Minas e Energia 2007). ${ }^{88}$ They were never directly counterpoised to the new kinds of electricity, and the wind and solar deployments of Figures 2.4 and 2.6 happened after they were already underway.

In short, if this were a book about oil production, Brazil would have issues of just transition and state capture that would parallel South Africa's. In the South African case, those problems spilled over into the planning and procurement of wind and solar power while they did not in Brazil. State capacity may explain that in part, with the Brazilian EPE mastering a technical planning process that used climate rationales, among others, to steadily add wind power to the national grid. The near absence of solar power until after 2014 is less readily comprehensible through the lens of either state capacity or climate policy.

\subsection{Conclusion}

This chapter uses the lens of the climate policy arena to investigate the development of wind and solar power in Brazil and South Africa. Major sections of the chapter examine whether and how coalitions of

88 Interview with Celso Knijnik, Director of Energy of the Program of Growth Acceleration (PAC), Brasília, 2018. 
state, civil society, and business actors in each country joined to write climate action commitments and then instantiate them in concrete electricity planning processes. The logic of the climate political economy includes two sides: the widespread but diffuse interest in action that will reduce future climate change by reducing GHG emissions and the concentrated interests that fossil fuel sectors have in resisting the existential threat of such action. Following the arguments of climate scholars, this requires a focus on the state's capacity to recognize that diffuse interest and then to formulate and implement policies even when powerful opponents resist. The two countries have fundamentally different starting positions in the climate political economy in that South Africa has a historically powerful coal-based electricity sector with many political and economic allies, while Brazil does not. In Chapter 1, I proposed that that difference should create inherently more conflictual and blocking dynamics around wind and solar power in the climate policy arena in South Africa, which might spill over to other domains. This chapter supports that proposal.

South Africa's state capacity to formulate and implement climate action was historically weak, especially compared to the powerful coalbased Minerals-Energy Complex. The DEA did slowly build the capacity to formulate climate institutions and policies after 2004, with some civil society and industry support. The larger story in South Africa, though, is of a country that has not quite been able to commit to either climate action or renewable energy. Even initial steps to break the monopoly of coal depended on more circumstantial developments, including an electricity supply crisis and Zuma's unexpected international climate action commitment at the 2009 negotiations in Copenhagen. Court cases brought by principled activists were most decisive in blocking the options of new nuclear or coal-fired power plants in the short term, skipping over limited state capacity to force climate action.

The state-controlled electricity parastatal Eskom has been the natural center of the anticipated opposition from the fossil fuel sector, as it is literally dependent on an economic model of generating electricity from coal. Eskom did not overtly block the development of climate policy altogether, although it and its allies raised many questions about specific instruments and time frames. The theoretically expected open resistance came to the building of wind and solar power itself. From the start, Eskom refused to follow a 2003 directive to include them and complied with early procurement of wind and solar power only as it struggled to 
generate enough electricity to meet national demand. But Eskom outright refused to sign contracts for wind and solar power from 2016 to 2018 until a change of national president brought it back into compliance. From 2011 to 2019, the Department of Energy's repeated efforts to update the electricity build planning documents showed widely fluctuating proposals about how much coal, nuclear, wind, and solar power should be built. All but the last, in late 2019 , were blocked by a coalition of Eskom, labor unions, and sectors of the governing ANC with close ties to Zuma. They insisted that any climate action commitments must be met with nuclear power, not wind and solar plants. Subsequent chapters will show that this mobilized opposition spilled over into other policy arenas and generally raised the levels of politicization and conflict around wind and solar power in South Africa.

The fundamental logic of the climate policy arena, where actors who are dependent on fossil fuel generation will strongly mobilize to protect their own interests against climate action, is clearly relevant. For most of these years, Eskom and its allies managed to outweigh the more limited capacity of state agencies like the DEA and the Department of Energy, which have favored wind and solar power installation. Over time, it has become increasingly clear that the fossil fuel coalition's systematic interest in protecting itself was also supported by the personal, corrupt interest of Zuma and a small group around him in building nuclear power. Thus, a state capture logic reinforced the more systematic climate logic in restricting wind and solar power development. By contributing to a broader weakening of Eskom's financial position and management capacity, however, those corrupt interests may have inadvertently helped lay a foundation for future climate action (Roberts and Geels 2019: 225).

In his first major international statement on climate change in September 2019, President Ramaphosa struck very different notes, stressing South Africa's self-interest and global responsibility to take on serious climate change commitments. He promised $\$ 11$ billion for a Just Transition Transaction Fund that was meant to recover Eskom's financial strength and protect coal workers while transitioning away from coal only to have his government post a new version without that promise two days later. ${ }^{89}$ Those would have been critical promises that set South Africa

89 www.dirco.gov.za/docs/speeches/2019/cram0923.htm; www .dailymaverick.co.za/article/2019-10-02-ramaphosas-11bn-climate-fund-orhow-the-smart-money-could-turn-mpumalanga-into-the-envy-of-the-world/. 
on a very different track, using just transition strategies to overcome the opposition from the fossil fuel sector. Their quick removal shows that South Africa continues to be deeply divided on how fully to take on a climate action agenda.

In contrast, Brazil does not have an incumbent fossil fuel sector in electricity generation, as it has relied mostly on hydropower. As a result, climate action debates - while contentious in themselves rarely focus on electricity. Almost all of Brazil's GHG emissions have historically come from deforestation. Brazil's Ministry of Environment and its allies did, after 2004, build some remarkable capacity to reduce deforestation, which set the stage for more ambitious climate policy in 2009-2010. Climate action commitments drew on support from many sectors of Brazilian society in the first decade of the 2000s before opposition from agribusiness rolled back some of the gains in the second decade. Proponents of the diffuse and future interests associated with climate action have had a difficult time countering the rural sector's more immediate economic interests. In his speech to the United Nations in September 2019, President Bolsonaro struck a defiant and aggressive tone, calling media reports on fires and deforestation in the Amazon falsehoods with a colonialist spirit and asserting Brazilian sovereignty over an abstract "global interest." On climate, he quoted the biblical verse John 8:32: "Know the truth and the truth will set you free." 90 Throughout these ups and downs in climate policy and action, wind and solar power themselves retained cross-partisan support in Brazil. Five presidents from four political parties favored them, even President Bolsonaro, who had few other pro-environment positions.

Their insulation from the heat of climate action debates left wind and solar power development in the domain of technical energy planners in Brazil, who unveiled their plans with few of the conflicts of the South Africans. Starting with an initial tranche in 2001 and then much more after 2009, they scheduled ever larger shares of wind power procurement for the national electricity grid. They pointed out that this could both complement and replace hydropower as a climate-friendly source of electricity, helping Brazil to meet its climate action commitments. Although the same could be said of solar power, this was largely left out

90

www.itamaraty.gov.br/pt-BR/discursos-artigos-e-entrevistas-categoria/presi dente-da-republica-federativa-do-brasil-discursos/20890-discurso-dopresidente-jair-bolsonaro-na-abertura-da-74-assembleia-geral-das-nacoesunidas-nova-york-24-de-setembro-de-2019. 
of the plans until 2014, despite Brazil's abundant solar resources. It is difficult to justify these different fates on climate grounds, suggesting that the difference between the two kinds of renewable energy must reflect the logic of one or more of the other chapters. However, the lowconflict approach to wind and solar power in Brazil is consistent with the larger political economy of climate change, as it derives from the absence of an equivalent actor to Eskom with its dependence on fossil fuels in the electricity sector.

The theoretical framing of this chapter posits that there is a widespread diffuse interest in reducing the emissions that result in climate change and asks to what extent the Brazilian and South African governments acknowledge that general interest. States do not only respond to the general interest, of course, but may also reflect the particular interests of politicians or institutions. In both countries, there were serious corruption scandals in the energy sector during the same years that wind and solar power were considered. Zuma and a small group of cronies targeted Eskom as one of the two state-controlled enterprises with the largest state procurement budgets. They pursued nuclear and coal projects from which they could personally benefit directly instead of wind and solar power, stunting the growth of the latter. There was also a widespread government procurement scandal in Brazil, which targeted the state-controlled oil company Petrobras and several large electricity projects, among many others. In the Brazilian case, the direct impact on wind and solar power acquisition was small. The influence of corrupt motivations in electricity procurement is not inevitable (it is different even in these two countries) and does not stem directly from the climate political economy. However, the clear possibility that public and private actors in the energy sector might seek private gains in large infrastructure projects should probably be recognized as an additional potential barrier to states' willingness and capacity to take effective decisions in favor of the public interest in a low-carbon energy transition. Ironically, the fact that it seems much more complicated to arrange corrupt schemes around the many small projects of wind and solar power, otherwise a virtue, may be an argument against them for actors looking for private gains. 